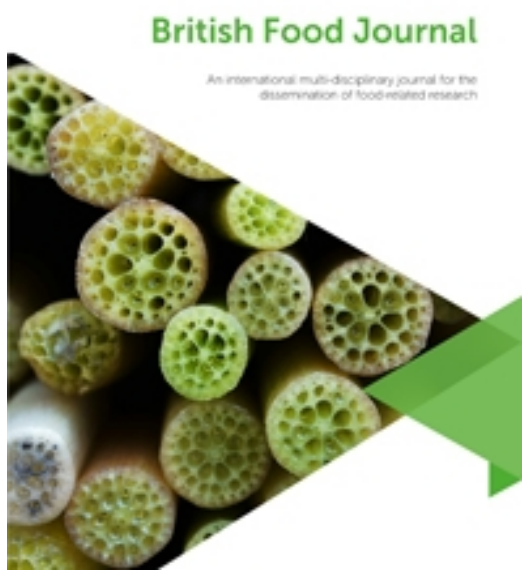

\title{
Accounting Conservatism and Income Smoothing Practices in EU Food and Drink Industry
}

\begin{tabular}{|r|l|}
\hline Journal: & British Food Journal \\
\hline Manuscript ID & BFJ-11-2020-1041.R1 \\
\hline Manuscript Type: & Research Paper \\
\hline Keywords: & Food \& Drink Industry, Accounting Conservatism, Income Smoothing \\
\hline \multicolumn{2}{|l}{} \\
\end{tabular}

\section{SCHOLARONE}

Manuscripts 


\section{Accounting Conservatism and Income Smoothing Practices in EU Food and Drink Industry}

\section{Introduction}

Accounting conservatism is a fundamental attribute and closely linked to the market. According to Basu (1997), 'Conservatism' is defined as "the tendency to require a higher degree of verification to recognize good news as gains than to recognize bad news as losses" showing the asymmetrical verification requirements for gains and losses. Therefore, conservatism means having higher verification requirements for losses than gains. Regulators, standard setters and firms defined 'Conservatism' as the accounting process likely to understate net assets and cumulative income (Kieso et al. 2004; Revsine et al.1999).

The purpose of this paper is to test the accounting conditional conservatism and of EU listed firms which operate in the EU Food \& drink sector for the reason that it represents the main domestic industry in all European countries (Abdel-Kader and Luther, 2006). This industry is the EU's biggest manufacturing sector in terms of value added. In the last 10 years, EU food and drink exports have duplicated, achieving over EUR 90 Billion and contributing to a positive balance of almost EUR 30 Billion (EU Commission, 2020). According to Mann et al. (1999b), this sector is also the biggest one in terms of employments for over three million people from primary producers to manufacturers and retailers. EU food and drink regulation is strongly harmonised and the industry can benefit from the opportunities offered by the EU Single Market. At the same time, however, the sector faces certain challenges in both international and European markets. There is also a need for an increased emphasis within the industry and its full supply chain network on the broader social and economic impact of food and drink production, distribution, purchasing and consumption. This industry is the driving force behind EU exports and boasts a very high reputation in the world. The above data make this industry such a dominant industry as well as a useful context of investigation for this research.

We verified whether such relevant industry is "protected" by accounting rules and whether the quality of earnings is in line with the market price. In addition, we would also examine the above relationship distinguishing two samples: the first with companies that adopt income smoothing practices and the second that don't. The results demonstrated the hypothesis that EU listed firms avoid the use of any earnings management practices and they have a greater ability to recognize future economic losses. In other words, the EU food and drink industry is considered "safeguarded" because the application of conservatism in earning recognition is associated with real companies values. We also found that the more companies employ income smoothing (i.e. adopt accruals to reduce the variability of profits), the more possibility there is for the timely acknowledgement of future economic losses.

This study bases its accounting conservative on "timely loss recognition" formulated by Basu (1997) in which earnings are regressed on the negative returns (as a proxy of "bad news"), the returns and the interaction variable of negative returns (proxied by a dummy variable) and returns themselves. This study shows a need for leading managers to provide further accounting disclosures to enhance the credibility to the financial statements. Moreover, there must be several steps towards developing corporate governance mechanisms in order to protect the investors and shareholders' interests.

Implications from this research are based on more monitoring of the accounting practices adopted by firms. The research can also generate a direct benefit to investors on food and drink industry through earlier recognition of losses in the income statement which, as a result, can generate greater market confidence. This empirical evidence suggests that the elimination of conservatism from accounting regulatory frameworks may lead to undesirable economic consequences in the EU context within the 
largest industry sector. Regulators might set accounting policies to enhance the quality of the informational environment; on the other hand, investors and shareholders might control the executives decisions, and, finally, lenders might set contractual clauses requiring the timely disclosure of "bad news".

To the authors' knowledge, this represents the first work that examined the characteristics and the determinants of accounting conservatism at EU level in such relevant industry.

The rest of the paper is articulated as follows: in the second section we present the economic data of EU food industry over the recent years justifying the importance of such sector in terms of value creation and jobs. In the third section we present the prior studies on accounting conservatism together with the hypotheses developed. The fourth section reports our data collection process, the sample and the methodology by which the statistical analysis is performed. The fifth section presents the descriptive statistics and the findings. Finally, the sixth section discusses the results and shows the contribution, implications and limitations of the study.

\section{EU Economic bulleting of food and drinks industry}

The food and drink sector represents the world's largest manufacturing industry and an integral part of the world's social, economic and cultural values contributing to the wealth development of countries. During the period of economic crisis in 2008-2014, the turnover grew by almost 7\%, while turnover in the overall manufacturing industry decreased by $0.8 \%$ (FoodDrinkEurope, 2016).

In 2016, as reported by the graph, the total turnover and the share of employment of EU Food and drink industry weighted at $15.1 \%$ and $15.5 \%$, respectively, to the total EU manufacturing industry representing the EU largest industry in terms of turnover and jobs.

\section{Inset Figure 1 about here}

\section{Inset Figure 2 about here}

In 2019, the EU food and drink industry includes 294,000 companies and employs 4,72 million workers for a total turnover of 1,192 billion of euros representing the largest manufacturing EU industry. In 2019, the trade showed $€ 110$ billion of exports and $€ 74$ billion of imports with a trade balance of $€ 36$ billion (FoodDrinkEurope, 2019).

Compared to the non-EU countries, 10 nations out of 15 in the top markets are based in Europe as showed by the graph below with the largest markets of exports for food and drinks industry in 2019.

\section{Inset Figure 3 about here}

In the first quarter of $2020, \mathrm{EU}$ food and drink industry production increased by $0.4 \%$ compared to the previous quarter as well as the turnover increased by $2.8 \%$ compared to the previous quarter (FoodDrinkEurope, 2020).

The year-on-year comparison shows that food and drink industry production growth exceeded total manufacturing production growth $(0.2 \%$ vs. $-4.9 \%$ compared to the first quarter of 2019$)$. The yearon-year growth in food and drink industry turnover exceeded that of total manufacturing industries 
(5.4\% vs. $-4.7 \%$ compared to the first quarter of 2019). The turnover in the Food\&drinks segment is projected to reach $€ 17,668 \mathrm{~m}$ in 2020 .

\section{Inset Figure 4 about here}

Furthermore, it is also expected to show a revenue growth of $9.9 \%$ in 2021.

\section{Inset Figure 5 about here}

\section{Theoretical Backgrounds and prior studies}

\subsection{Conditional and Unconditional Conservatism}

The conservatism principle has been studied since the fifteenth century, pre-dating Pacioli's treatise on accounting bookkeeping (Andrè et al, 2015). According to Dickhaut et al. (2010) the conservatism avoids the overstatement of net assets and income, limiting actions of earnings manipulation.

Givoly and Hayn (2000) pointed out that conservatism is the selection criterion between accounting principles that leads to the minimization of cumulative reported earnings and net assets by lower revenue recognition and lower asset valuation. According Kieso et al. (2004) and Revsine et al. (2005) 'Conservatism' is the accounting process likely to understate net assets and cumulative income. Balachandran and Mohanram (2011, p.275) discussed conservatism as "the downward bias in book values relative to market" values (Beaver and Ryan 2000) or "downward bias because of specific accounting practices" (Penman and Zhang 2002).

The debate of international doctrine on accounting conservatism is based on two types of conservatism: unconditional conservatism and conditional conservatism (Beaver and Ryan, 2005; Nasev, 2009). Under unconditional conservatism, the book value of net assets is understated due to predetermined aspects of the accounting process (Beaver and Ryan, 2005) and is not conditioned on the economic reality (Jenkins et al., 2009). Write-off items do correspond to accounting policies as proxied by the period of the asset such as the recognition of depreciation expense of an asset over 8 years instead of 10 years is likely to lower current earnings.

Conditional conservatism stands for reporting accounting numbers conditional on the firm experiencing contemporaneous economic loss. It therefore captures the timely recognition of accounting loss. Conditional conservatism has affected accounting policies and represents one of the most fundamental pillar in accounting and reporting (Watts, 2003).

However, the International Accounting Standards Board (IASB) has been issuing a strong push for the "fair value" accounting that essentially represents the opposite of conditional conservatism requires symmetric timeliness: the recognition of 'good news' is not postponed so that both good news and bad news are accounted (Kim and Pevzner, 2010). The conditional conservatism only demands deferred recognition of 'good news'.

Ball and Shivakumar (2005, p. 91) state that "while unconditional conservatism seems inefficient or at best neutral in contracting, conditional conservatism (timely loss recognition) can enhance contracting efficiency". In this paper, the focus is on conditional conservatism meaning the timely recognition of economic losses on EU food and drink industry. In line with prior studies, we seek to test the following hypothesis: 
$H_{1 a} \rightarrow$ Companies with higher accounting conditional conservatism practices are likely to have higher market values in EU food \& drink industry

\subsection{Income smoothing}

Income smoothing refers to the usage of accounting practices to level out fluctuations in earnings over the period. Companies usually adopt this technique because investors are much willing to pay a stock premium with steady and predictable earnings streams as opposed to stocks whose earnings are subject to more volatile patterns. According to Beidleman (1973, p. 653), income smoothing is related to the "dampening of fluctuations about some level of earnings that is currently considered to be normal for a firm".

Above all, there is one main reason that lead companies into smoothing the earnings of the economic unit and it is based on investor confidence improvement; specifically, economic unity is achieved through a stable earning as well as a stability of earnings per share. In turn of this stability, this produce higher market values and, thus, higher interests from potential investors by maximizing their wealth and their confidence in economic unit consequently enhanced (Steven \&Yoonseok, 2009).

Income smoothing can be intentional or natural (Albrecht and Richardson, 1990). Intentional can be set by timing real business decisions (real smoothing) or by selecting accounting policies that allocate earnings over time in the desired manner (artificial smoothing). On the other hand, natural practices include mechanisms of the accrual process where management do not manipulate (Gassen et al. 2006). Some scholars (Dechow and Skinner, 2000; Fudenberg and Tirole, 1995) argue that artificial income smoothing is a form of earnings management and represents the earnings manipulation through the accrual process to make the earnings flow less fluctuating, while not increasing or decreasing equity in the long term. By representing a discretionary attribute of earnings, income smoothing provides data for the capital markets and rational investors may not be misled by this practice, since returns (economic earnings) and cash flows (cash earnings) are observable. Income smoothing can provide a signal (Barnea et al., 1976) that in case it is verifiable and management owns private information about earnings in the future, this practices represents a vehicle to publicly communicate this information. On the contrary, if the signal is not verifiable, income smoothing is ignored by market participants.

The conditional conservatism and income smoothing represent two main elements that can strongly affect the quality of the financial information that is communicated to the market (Ryan, 2006). Gassen et al. (2006) state that conditional conservatism is positively associated with the degree of indebtedness of firms, as income smoothing affects firms' dividend policies. The results support the theoretical claim that smoothing interferes with a firm's capacity to recognize bad economic news (i.e., economic losses).The reduction of optimism from the market represents the result of income smoothing practices that are intended to prevent profits from appearing to be too far above or below market expectations. Thus, conservatism and smoothing, can result in a reduction of optimism. On the other hand, companies that have no experience in income smoothing practice are seen with much optimism, and thus their accounting conservatism indicates an high quality level of earnings. From here the second main hypothesis to be tested:

$H_{1 b} \rightarrow$ Companies that have not experienced income smoothing practices are likely to have a strong level accounting conditional conservatism practices in EU food \& drink industry

\section{Research method}

\subsection{Sampling process}




\title{
4.2. Model specification
}

\section{Inset table I about here}

\section{Inset table II about here}

\author{
Inset table III about here
}

Our analysis uses Basu's (1997) model to test the conservatism principle as earnings that capture bad news faster than good news, also called timely loss recognition. He stated that conservatism relies to "capturing accountants' tendency to require a higher degree of verification for recognizing good news than bad news in financial statements" (Basu, 1997).

Adopting stock returns to measure for good and bad news, we expected that in a reverse regression of earnings on stock returns, a higher association of earnings with negative stock returns than with positive stock returns would be observed (Amran \& Abdul Manaf, 2014).

Consistent with prior research (Andrè et al., 2015), the asymmetric treatment of losses and gains is captured by the piecewise-linear regression of accounting earnings on stock returns:

$$
\boldsymbol{E}_{\boldsymbol{t}}=\beta_{0}+\beta_{1} \boldsymbol{D}_{\boldsymbol{i}}+\beta_{2} \boldsymbol{R}_{i t}+\beta_{3} \boldsymbol{D}_{\boldsymbol{i}} * \boldsymbol{R}_{\boldsymbol{i t}}+\varepsilon_{i, t}(1)
$$

where $E_{t}$ is annual net income per share after taxes and before extraordinary items lagged by the market value per share at beginning of period ( $t-1), R_{i t}$ is a twelve-month stock return that indicates the return on the share in period $t$ by accumulating the price differentials of the 12 months in period $t, D_{i}$ is a dummy variable assuming the value of one if stock return $(R)$ is negative and equals zero otherwise, and $\varepsilon_{i, t}$ is the residual term. According to the model, timely loss recognition supports the principle of prudence that negative returns are recognized faster than positive returns. Therefore, the higher the value of the coefficient associated with $\beta 3$, the greater the positive relationship between the application of conservatism and the value relevance. The coefficient $\beta 3$ indicates the sensitivity of earnings to negative stock returns and it is expected to be positive and significant when earnings are more sensitive to negative stock returns than to positive stock returns.

In order to test the model in two different samples (companies which adopt income smoothing or not), we used the Eckel's model (1981) based on the assumption that revenues and expenses are linear over time meaning that they grow or decline at the same rate. According to Eckel (1981) and Leuz et al (2003), when a linear relationship between revenues and sales is not observed, this property may be due to interference from executives to smooth the results.

To test the relationship between profits and revenues, the coefficients of the percentage variations of net income and sales revenue are computed. In case the coefficient of the net earnings is less than that 
of the revenue, this shows that the company is interfering in the profits through artificial smoothing, as reported below:

$$
0.9 \leq \frac{C V \Delta \% \text { Net Income }}{C V \Delta \% \text { Sales }} \leq 1.1
$$

This indicates that if the ratio's result is less than 0.9 , the company performs income smoothing; on the other hand, if the ratio is higher than 1.1, the company does not perform income smoothing. This method allows for the objective classification of selected companies, thus decreasing risk of bias. The companies that record results within that range (from 0.9 to 1.1 ) were excluded, as showed by the processing of the sample shown in Table IV.

\section{Inset table IV about here}

\section{Regression results}

\subsection{Descriptive statistics}

\section{Inset table $\mathrm{V}$ about here}

Table V presents the descriptive statistics for the variables used in our model. The mean value of net earnings hare adjusted by the stock price at the beginning of the firm year is 0.015 , the minimum value is -0.970 while the maximum value is 0.430 . The twelve-month stock return that indicates the return on the share in period $t$ by accumulating the price differentials of the 12 months in period $t$ shows an average value of -0.0745 , a minimum value is -0.910 while the maximum value of 0.780 . The number of observations for all variables are 308 meaning since there are no missing values.

\subsection{Findings}

Table VI discloses the output of the regression model with interaction terms that we used to test our research hypothesis. Table 6 (Panel a - Total Sample) shows no statistical significance for the variables $R$ and $D$ while the interaction term $(R \times D)$ is positive $(0.1542)$ and statistically significant at $10 \%$. Results from total sample show that timely loss recognition supports the principle of prudence that negative returns are recognized faster than positive returns. The variable $\mathrm{RxD}$ is found to be positively $(+0.1542)$ and statistically significant (P-Value at $10 \%$ level) to the market values. The coefficient of $\mathrm{RxD}$ on the market return measures the timeliness of gain recognition or the responsiveness of earnings to good news, while the sum of $\beta_{2}+\beta_{3}$ measures the timeliness of loss recognition or the responsiveness of earnings to bad news. As reported by Pope and Walker (1999), the $\beta_{3}$ coefficient $(+0.1542)$ measures incremental timeliness of loss recognition. We found positive and significant coefficient $\beta_{3}$ that implies asymmetric timely loss recognition and therefore conditional conservative accounting (Pope and Walker, 1999; Ball et al., 2000).

This can lead to the interpretation by which the higher the value of $\mathrm{RxD}$, the greater the positive relationship between the application of conservatism and the value relevance. $\mathrm{RxD}$ demonstrates a positive sensitivity of earnings to negative stock returns. 
Finally, we found that the classification of EU listed companies in food and drink into groups of smoothers and non-smoothers based on Eckel's (1981) model justified the application of Basu's (1997) conditional conservatism model. In our case showed in the above table, for the sample of smoothers companies the variable $\mathrm{RxD}$ is positive (coefficient 0.2772 ) and statistically significant at $5 \%$ level while the sample of smoothers companies does not show any significance level of the interaction variable. According to the theory behind the present study, firms that smooth results eventually interfere with the results they disclosed by, for example, provisioning more or adjusting depreciation, amortization, or other accruals that ultimately distort the economic realities of the business; this makes it difficult for the market to recognize anticipated economic losses in profits. For this reason, the interaction variable is not significant.

\section{Discussion and conclusions}

The successful application of conservatism in EU listed companies belonging Food and Drink means achieving better quality financial reporting. We examine conditional conservatism - an important qualitative characteristic of financial reporting - and document that this produces an increasing of market values.

Accounting policies should be seen as critical components that will enable investors to be more conscious about the opportunity of realizing returns from their investments. In this research, we would test the accounting conservatism in food and drink industry that is the driving force of EU economic fabric. From here, it is necessary to verify whether this industry is "protected" by accounting rules and whether the quality of earnings is able to explain the market price. The results from this study show that higher conservative practices by these companies will affect the informativeness of financial estimates increasing stock returns. In doing so, these findings from food and industry sector can be considered as an outcome of the markets assessment of disclosure credibility.

We demonstrated that the hypothesis that EU listed firms have a greater ability to recognize future economic losses providing high quality of accounts. In other words, the EU food and drink industry is considered "safeguarded" because the application of conservatism in earnings recognition is associated with real companies value. Furthermore, we have also assessed how the practice of nonsmoothing of earnings can influence the conservatism.

We contribute to the academic debate by verifying the earnings quality of the largest European listed companies which operate in food and drink industry. It is extremely important to focus on such industry representing the largest EU business sector. The originality relies to show that this sector is strongly "belted" and from any external speculations. 
To make the results more robust, we have also included a further analysis distinguishing between companies that practice income smoothing activities and company that do not. We found a strong level of conservatism within companies that do not practice income smoothing that satisfy the hypothesis $1 b$.

Our results must be also taken considering the primary opportunities for foodservice and food retail industries to address their environmental issues, not primary issues in this paper, but not less important such as reducing energy intensity of operations through efficiency efforts, enhancing recycling efforts of secondary or tertiary packaging waste, incorporating safety programs such as HACCP, encouraging vertically integrated firms (mostly grocery retailers) to improve the financial and environmental performance, encouraging strategic alliances with suppliers, etc.

Some recommendations must be addressed. One posits to the fact that financial reporting council and other allied bodies must ensure clarity and provide rules with probably less discretionary tendencies for management to manipulate. In general terms, the direction of the relationship between conservatism and value relevance is unclear and it can be generalized since results from industries are different. Several scholars describe accounting treatments as "trade-offs" between relevance and reliability (Bandyopadhyay et al., 2009; Entwistle and Phillips, 2003; Stanga, 1980); furthermore when the regulators are criticized, the critiques commonly portray regulations as having erred in the favour of one side at the expense of the other. The presumption behind trade-off is that relevance decreases in conservatism. Therefore, the financial reporting council and other allied regulatory bodies must ensure clarity and provide rules with probably less discretionary tendencies for management to manipulate with the scope of enhancing the credibility of accounting data.

IMPLICATIONS_ These results within the food and drink sector identified in this paper point to several policy implications. Practical implications are based on more monitoring of the accounting practices adopted by firms. Regulators have set accounting policies to enhance the quality of the informational environment; on the other hand, investors and shareholders might control the executives decisions, and, finally, lenders might set contractual clauses requiring the timely disclosure of "bad news". Most importantly, accounting regulators must not drastically modified the structure and content for accounts recognition. In other words, this analysis does indicate a regulatory success of accounting standards in this industry and lead to the conclusion that regulators had developed rules that ensure the quality of accounting conservatism. Regulators activities seem to be appropriate, that does mean that improved accounting conservatism by the food \& beverage industries should be achieved.

FUTURE RESEARCH There is considerable scope for developing new research. This paper illustrates the importance of considering the accounting conservatism of food and beverage sectors broadly, looking beyond the level of earnings quality. In this respect, the conceptual framework of IASB is useful tool that can be applied to future research of food and drink industries focuses on specific accounts such as IAS 2 and/or IAS 18, extremely important for this industry. Another stream of research is proposing a comparative analysis with other industries: while the relative importance of such impact may differ by industry, it is undoubtedly critical to evaluate each to capture the full magnitude of conservatism and to identify the levers for managing earnings quality. Furthermore, the focus on environmental issues is also critical in this sector: it would be useful to provide an analysis with the impact of environmental aspects. Moreover, since this issue is not unique to this sector, their management will likely best be accomplished if targeted on a cross-industry basis, with perhaps industry-specific implementation strategies designed to ensure opportunities to maximize flexibility, efficiency, and innovation. Further research areas would search for new methods to analyze the quality of companies' accounting choices. The association among accounting methods and phenomena would also be investigated, together with market factors or incentives that may influence managers' decisions between different accounting practices. In addition, further researches may test 
potential "industry-specific" accounting practices that are frequently used to influence outcomes arising from environmental incentives, as well as recognizing those industries in which companies belong to. In addition to continued empirical and quantitative research we also need better integration between types of different research methodologies encouraging more interview studies, high-quality surveys, and more improvements of the theoretical foundations of accounting choice. I would expect to see a modest shift of research resources away from archival research and towards the other research methods. Nevertheless, our results provide a detailed, large-scale survey of the perceived importance and actual use of conservatism accounting practices in the industry and an indication of future trends. They suggest that European food and beverage companies show strong and perfectly credible financial statements towards potential investors.

Finally, we may need to pay more attention to the determinants of conservatism. What causes the best form of value relevance through conservatism and what can we do to ensure it? What are the determinants in order to deliver high quality earnings, and how can we facilitate other firms in different industry to emulate food and drink sector? What can be the corporate governance mechanisms to protect those firms?

\section{References}

Abdel-Kader, M. and Luther, R. (2006), "Management accounting practices in the British food and drinks industry", British Food Journal, Vol. 108 No. 5, pp. 336-357.

Albrecht, W.D. and Richardson, F. M. (1990), "Income smoothing by economy sector” Journal of Business Finance \& Accounting, Vol. 17 No. 5, pp. 713-730.

Amir, E. (1996), "The effect of accounting aggregation on the value-relevance of financial disclosures: The case of SFAS No. 106", The Accounting Review, pp. 573-590.

Amran, N.A. and Abdul Manaf, K.B. (2014), "Board independence and accounting conservatism in Malaysian companies", Procedia-Social and Behavioral Sciences, Vol. 164, 403-408.

André, P., Filip, A. and Paugam, L. (2015), "The effect of mandatory IFRS adoption on conditional conservatism in Europe", Journal of Business Finance \& Accounting, Vol. 42 No. 3-4, pp. 482-514.

Balachandran, S. and Mohanram, P. (2011), "Is the decline in the value relevance of accounting driven by increased conservatism?", Review of Accounting studies, Vol. 16 No. 2, pp. 272301.

Ball, R. and Brown, P. (1968), "An empirical evaluation of accounting income numbers", Journal of accounting research, pp. 159-178.

Ball, R., Kothari S.P. and Robin, A. (2000), “The Effect of International Institutional Factors on

Properties of Accounting Earnings", Journal of Accounting and Economics, Vol. 29 No. 1, pp. $1-51$.

Ball, R. and Shivakumar, L. (2005), "Earnings Quality in U.K. Private Firms: Comparative Loss

Recognition Timeliness", Journal of Accounting and Economics, Vol. 39, pp. 83- 128.

Bandyopadhyay, S.P., Chen, C., Huang, A.G. and Jha, R. (2009), "Accounting conservatism and the temporal trends in current earnings' ability to predict future cash flows versus future earnings: Evidence on the trade-off between relevance and reliability", Contemporary Accounting Research, Forthcoming.

Barnea, A., Ronen, J. and Sadan, S. (1976), "Classificatory smoothing of income with extraordinary items", The Accounting Review, Vol. 51 No. 1, pp. 110-122.

Basu, S. (1997), "The conservatism principle and the asymmetric timeliness of earnings", Journal of 
Accounting and Economics, Vol. 24, pp. 3-37.

Beaver, W. and Ryan, S. (2005), "Conditional and Unconditional Conservatism: Concepts and Modeling”, Review of Accounting Studies, Vol. 10, pp. 269- 309.

Beidleman, C.R. (1973), "Income smoothing: The role of management", The Accounting Review, Vol. 48 No. 4, pp. 653-667.

Bowen, R.M. (1981), "Valuation of earnings components in the electric industry", The Accounting Review, Vol. 56, pp. 1-22.

Collins, D.W., Maydew, E.L. and Weiss, I.S. (1997), "Changes in the value-relevance of earnings and book values over the past forty years", Journal of Accounting and Economics, Vol. 24 No. 1, pp. 39-67.

Dechow, P.M. and Skinner, D.J. (2000), "Earnings management: Reconciling the views of accounting academics, practitioners, and regulators", Accounting horizons, Vol. 14 No. 2, pp. 235-250.

Dickhaut, J., Basu, S., McCabe, K. and Waymire, G. (2010), "Neuroaccounting: Consilience between the Biologically Evolved Brain and Culturally Evolved Accounting Principles", Accounting Horizons, Vol. 24 No. 2, pp. 221-5.

Easton, P.D. and Harris, T.S. (1991), "Earnings as an explanatory variable for returns", Journal of Accounting Research, Vol. 29 No. 1, pp. 19-36.

Eckel, N. (1981), "The income smoothing hypothesis revisited", Abacus, Vol. 17 No. 1, pp. 28-40.

Entwistle, G.M. and Phillips, F. (2003), "Relevance, reliability, and the earnings quality debate", Issues in accounting education, Vol. 18 No. 1, pp. 79-92.

EU Commission (2020). Food and drink industry. Accessed 08 October 2020 at link https://ec.europa.eu/growth/sectors/food_en\#: :text=The\%20food $\% 20$ and $\% 20$ drink $\% 20$ ind ustry,specialities\%20are\%20well\%20appreciated\%20overseas.

Fairfield, P.M., Sweeney, R.J. and Yohn, T.L. (1996), "Accounting classification and the predictive content of earnings", The Accounting Review, pp. 337-355.

FDEA (Food and Drink Exporters Association, 2019). Retrived from https://www.fdf.org.uk/corporate_pubs/FDF-Industry-Report-2020.pdf

FoodDrinkEurope. (2016). A competitive EU food and drink industry for growth and jobs: Ambitions for 2025 - Priorities and policy recommendations. Retrieved from www.fooddrinkeurope.eu. Accessed on October 12, 2020

FoodDrinkEurope. (2019). Data \& Trends. EU Food \& Drink Industry 2019. Retrieved from www.fooddrinkeurope.eu. Accessed on October 12, 2020.

FoodDrinkEurope. (2020). FoodDrinkEurope \& EFFAT Joint Statement: Covid-19. Retrieved from www.fooddrinkeurope.eu. Accessed on October 12, 2020

Francis, J. and Schipper, K. (1999), “Have financial statements lost their relevance?”, Journal of Accounting Research, Vol. 37 No. 2, pp. 319-352.

Fudenberg, D. and Tirole, J. (1995), "A theory of income and dividend smoothing based on incumbency rents", Journal of Political Economy, Vol. 103 No. 1, pp. 75-93.

Gassen, J., Fülbier, R.U. and Sellhorn, T. (2006), "International differences in conditional conservatism: the role of unconditional conservatism and income smoothing", European Accounting Review, Vol. 15 No. 4, pp. 527-564.

Givoly, D. and Hayn, C. (2000), "The changing time-series properties of earnings, cash flows and accruals: Has financial reporting become more conservative?", Journal of Accounting and Economics, Vol. 29 No. 3, pp. 287-320.

Jenkins, D.S., Kane, G.D. and Velury, U. (2009), "Earnings conservatism and value relevance across the business cycle", Journal of Business Finance \& Accounting, Vol. 36 No. 9-10, pp. 10411058 . 
Kieso, D., Weygandt, J. and Warfield, T. (2004), Intermediate accounting, New York, NY: Wiley. Kim, B.H. and Pevzner, M. (2010), "Conditional accounting conservatism and future negative surprises: An empirical investigation", Journal of Accounting and Public Policy, Vol. 29 No. 4, pp. 311-329.

Leuz, C., Nanda, D. and Wysocki, P.D. (2003), "Earnings management and investor protection: an international comparison", Journal of Financial Economics, Vol. 69 No. 3, pp. 505-527.

Lev, B. and Zarowin, P. (1999), "The boundaries of financial reporting and how to extend them", Journal of Accounting research, Vol. 37 No. 2, pp. 353-385.

Mann, R., Adebanjo, O. and Kehoe, D. (1999b), "Best practices in the UK food and drinks industry", British Food Journal, Vol. 101 No. 3, pp. 184-99.

Nasev, J. (2009), Conditional and unconditional conservatism: Implications for accounting based valuation and risky projects, Springer Science \& Business Media.

Ohlson, J.A. (1995), "Earnings, book values, and dividends in equity valuation", Contemporary accounting research, Vol. 11 No. 2, pp. 661-687.

Penman, S.H. and Zhang, X.J. (2002), "Accounting conservatism, the quality of earnings, and stock returns", The Accounting Review, Vol. 77 No. 2, pp. 237-264.

Pope, P.F. and M. Walker (1999), "International Differences in the Timeliness, Conservatism, and Classification of Earnings", Journal of Accounting Research, Vol. 37, pp. 53-87.

Revsine, L., Collins, D.W., Johnson, W.B., Mittelstaedt, H.F. and Soffer, L.C. (1999), Financial reporting \& analysis, Upper Saddle River, New Jersey New Jersey: Prentice Hall.

Richardson, G. and Tinaikar, S. (2004), "Accounting based valuation models: what have we learned?”, Accounting \& Finance, Vol. 44 No. 2, pp. 223-255.

Ryan, S.G. (2006), "Identifying conditional conservatism", European Accounting Review, Vol. 15 No. 4, pp. 511-525.

Stanga, K.G. (1980), "The relationship between relevance and reliability: Some empirical results", Accounting and Business Research, Vol. 11 No. 41, pp. 29-39.

Statista (2020). https://www.statista.com/outlook/253/100/food-beverages/worldwide\#market-users. Accessed October 12, 2020.

Watts, R.L. (2003), “Conservatism in accounting part I: Explanations and implications”, Accounting horizons, Vol. 17 No. 3, pp. 207-221.

Zhang, X.J. (2000), "Conservative accounting and equity valuation", Journal of Accounting and Economics, Vol. 29 No. 1, pp. 125-149. 
Figure 1 - Share of turnover in the EU manufacturing industry (2016, \%). Source: FoodDrinkEurope (2019)

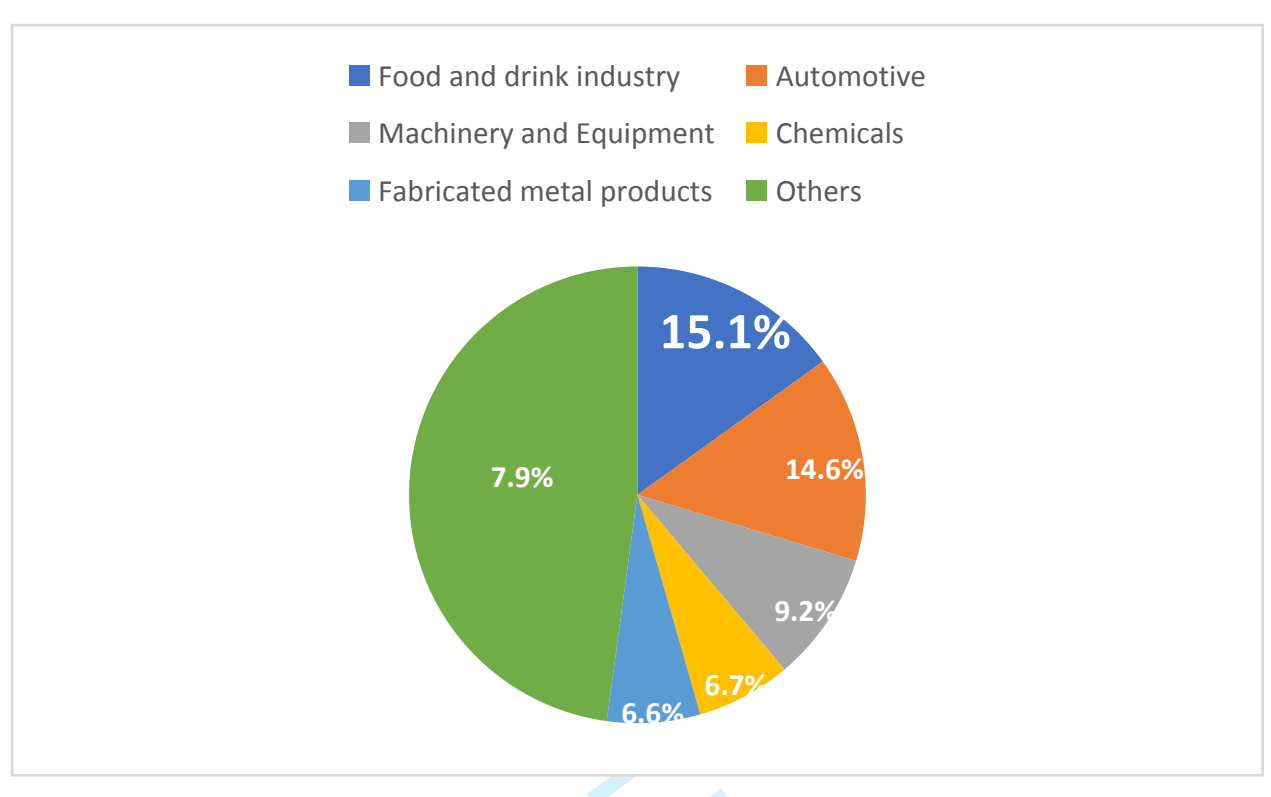

Figure 2 - Share of employment in the EU manufacturing industry (2016, \%). Source: FoodDrinkEurope (2019)

$$
\begin{aligned}
& \text { Food and drink industry } \quad \text { Automotive } \\
& \text { Machinery and Equipment } \quad \text { Fabricated metal products } \\
& \text { Others }
\end{aligned}
$$

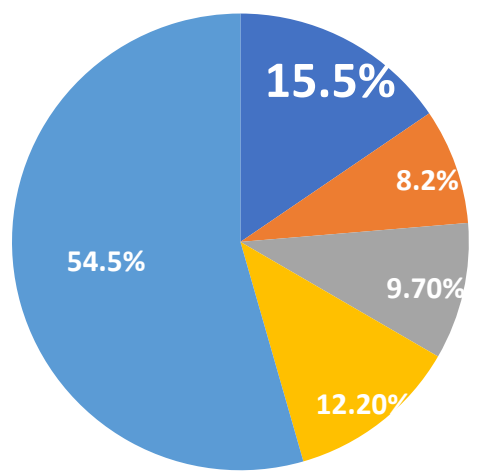


Figure 3 - Top markets in food and drink industry (data in $£ / m i l l i o n)$. Source: FDEA (Food and Drink Exporters Association, 2019). Retrived from https:/www.fdf.org.uk/corporate_pubs/FDF-IndustryReport-2020.pdf

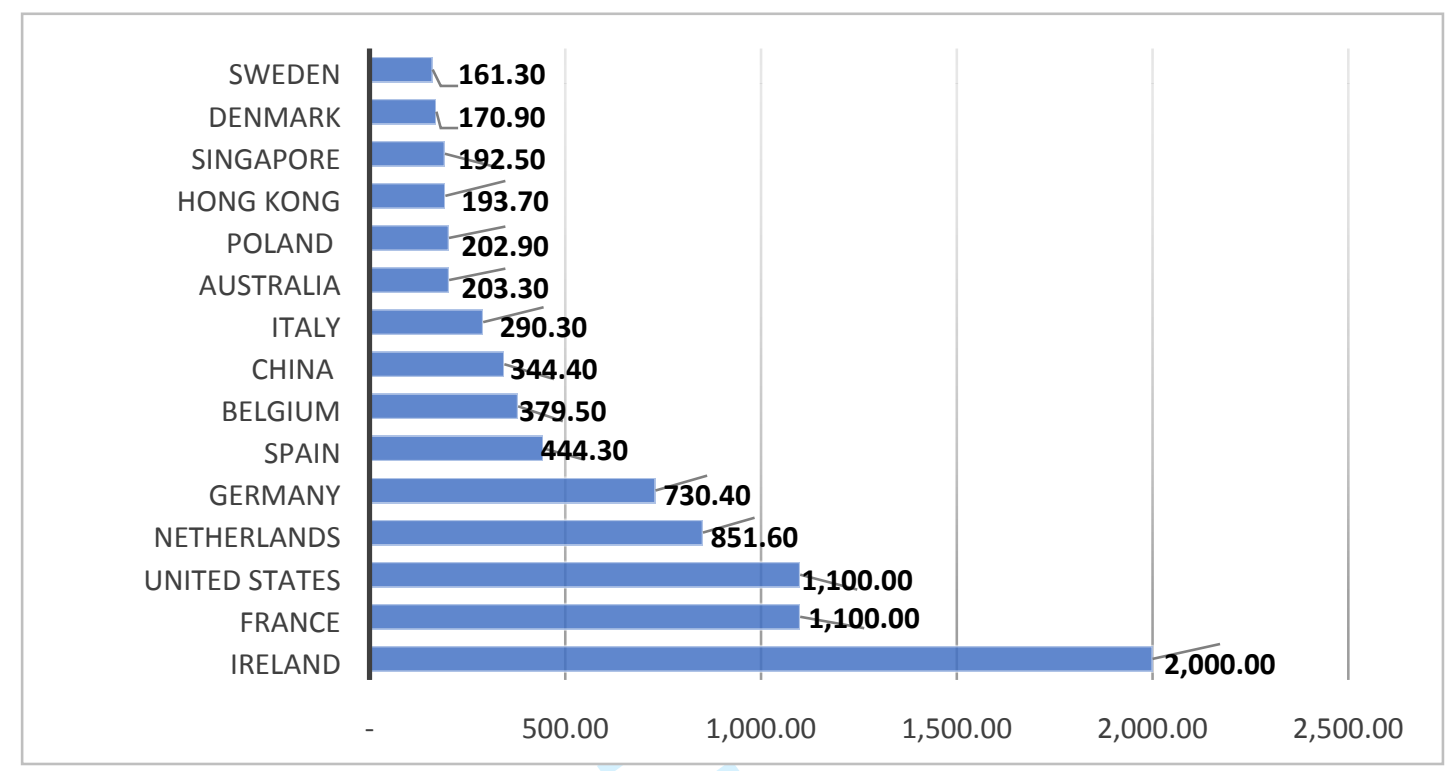

Figure 4 - Forecasted total turnover in Food and drink segment (€/million). Source: Statista (Forecast adjusted for expected impact of Covid-19. August 2020

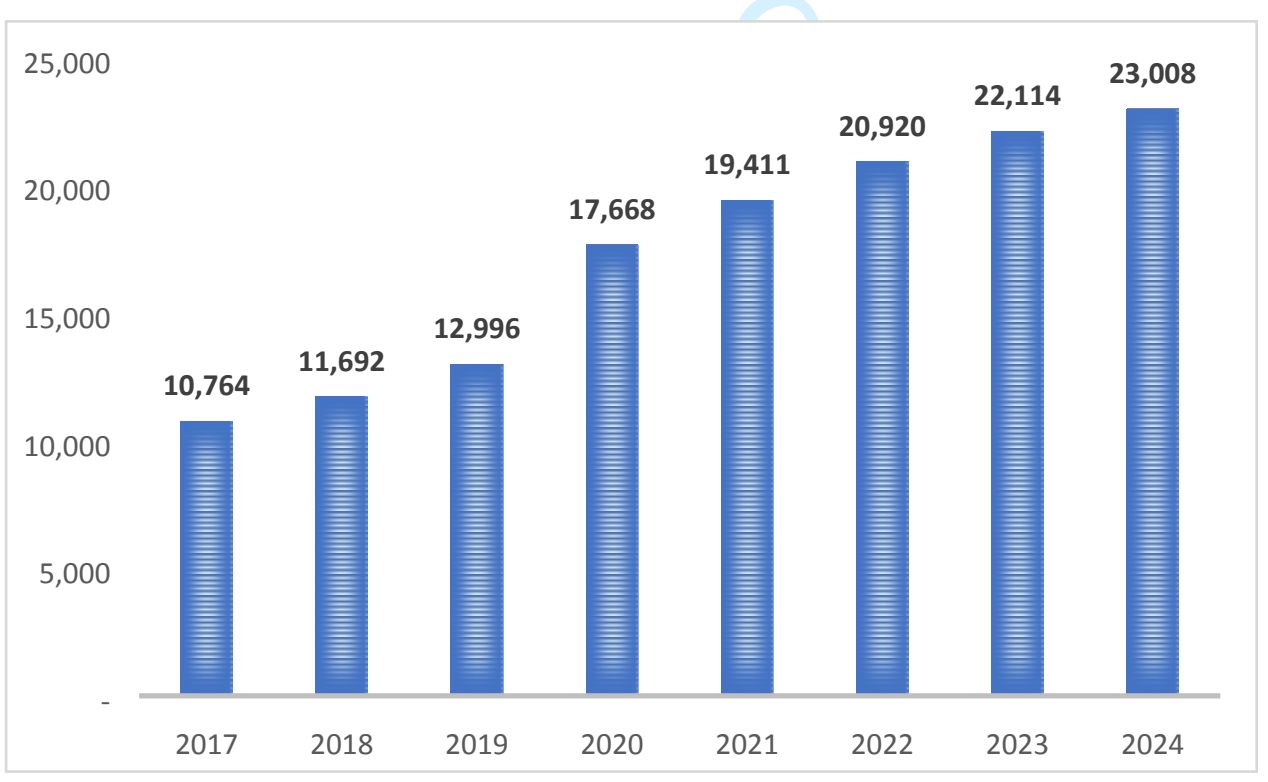

Figure 5 - Forecasted trend \% of total turnover in Food and drink segment. Source: Statista (Forecast adjusted for expected impact of Covid-19. August 2020 


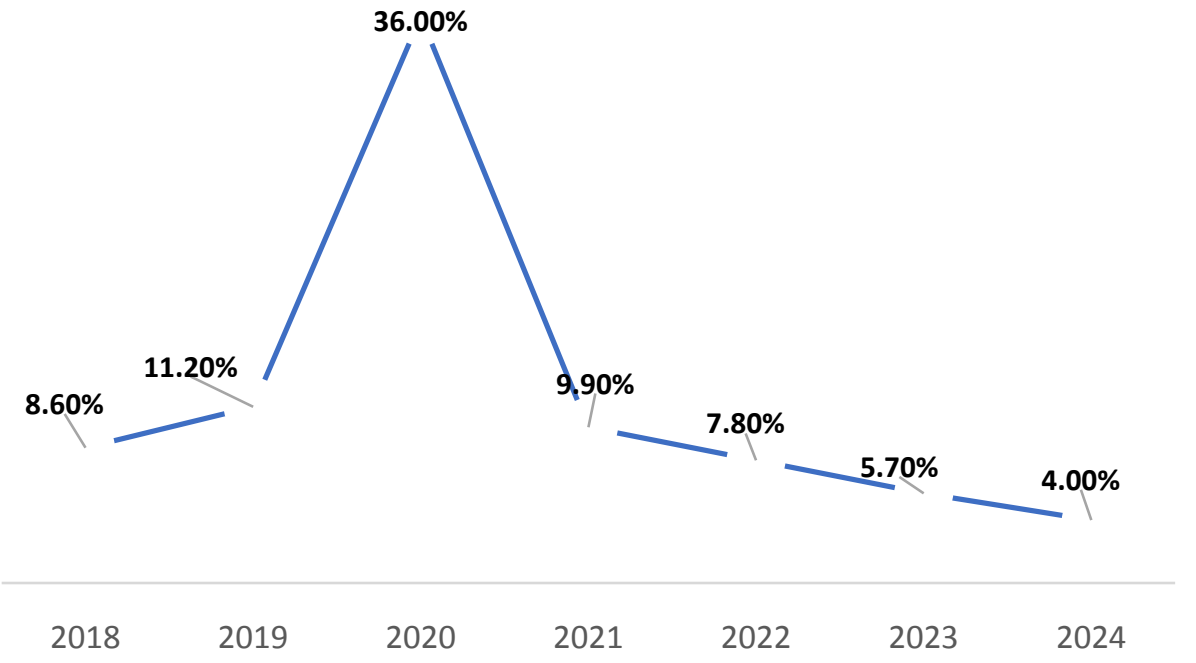


Table 1 - Sampling process

\begin{tabular}{lr}
\hline Data from Thomson Reuters & Number of observations \\
\hline EU listed companies in Food \& Drink & 358 \\
Companies not included because of missing data & 50 \\
Companies sampled & 308 \\
\%coverage & $88 \%$ \\
\hline
\end{tabular}

Table II - Sub-industry observations

\begin{tabular}{lr}
\hline & Total sample \\
\hline Food Manufacturing & 187 \\
Food Retailing & 45 \\
Beverage & 76 \\
Total & 308 \\
\hline
\end{tabular}

Table III - Country analysis

\begin{tabular}{|c|c|c|c|c|c|}
\hline Austria & 4 & $1.30 \%$ & Latvia & 2 & $0.65 \%$ \\
\hline Belgium & 12 & $3.90 \%$ & Lithuania & 6 & $1.95 \%$ \\
\hline Bulgaria & 6 & $1.95 \%$ & Luxembourg & 6 & $1.95 \%$ \\
\hline Croatia & 11 & $3.57 \%$ & Malta & 1 & $0.32 \%$ \\
\hline Cyprus & 7 & $2.27 \%$ & Netherlands & 10 & $3.25 \%$ \\
\hline Czech Republic & 1 & $0.32 \%$ & Norway & 11 & $3.57 \%$ \\
\hline Denmark & 5 & $1.62 \%$ & Poland & 22 & $7.14 \%$ \\
\hline Estonia & 3 & $0.97 \%$ & Portugal & 3 & $0.97 \%$ \\
\hline Faroe Island & 1 & $0.32 \%$ & Rep of Serbia & 6 & $1.95 \%$ \\
\hline Finland & 8 & $2.60 \%$ & Romania & 11 & $3.57 \%$ \\
\hline France & 28 & $9.09 \%$ & Russia & 10 & $3.25 \%$ \\
\hline Germany & 24 & $7.79 \%$ & Slovenia & 3 & $0.97 \%$ \\
\hline Greece & 12 & $3.90 \%$ & Spain & 7 & $2.27 \%$ \\
\hline Hungary & 2 & $0.65 \%$ & Sweden & 14 & $4.55 \%$ \\
\hline Island & 4 & $1.30 \%$ & Switzerland & 9 & $2.92 \%$ \\
\hline Ireland & 7 & $2.27 \%$ & Ukraine & 5 & $1.62 \%$ \\
\hline Italy & 11 & $3.57 \%$ & United Kingdom & 36 & $11.69 \%$ \\
\hline
\end{tabular}

Table IV - Samples of Income Smoothing and not

\begin{tabular}{rr}
\hline & $\begin{array}{r}\text { Companies } \\
\text { selected }\end{array}$ \\
\hline Non-Income Smoothing & 120 \\
Income Smoothing & 178 \\
Grey Area & 10 \\
Total & 308 \\
\hline
\end{tabular}


Table V - Descriptive data

\begin{tabular}{lrrrrr}
\hline Variable & Obs & Mean & Std. Dev. & Min & Max \\
\hline & & & & & \\
E & 308 & 0.0154 & 0.1320 & -0.97 & 0.43 \\
R & 308 & -0.0745 & 0.2489 & -0.91 & 0.78 \\
D & 308 & 0.6591 & 0.4748 & 0 & 1 \\
RxD & 308 & -0.1314 & 0.1695 & -0.91 & 0 \\
\hline
\end{tabular}

\begin{tabular}{lll}
\hline Dummy & Obs & $\%$ \\
\hline $\mathrm{D}=1$ & 203 & $65.9 \%$ \\
$\mathrm{D}=0$ & 105 & $34.1 \%$ \\
& 308 & $100 \%$ \\
\hline
\end{tabular}

Table VI - Regression results' on total sample and sub-samples

\begin{tabular}{|c|c|c|c|c|}
\hline Variable & Total Sample & $\begin{array}{c}\text { Sub-sample } 1 \text { - } \\
\text { Food Manufacturing }\end{array}$ & $\begin{array}{l}\text { Sub-sample } 2 \text { - } \\
\text { Food Retailing }\end{array}$ & $\begin{array}{c}\text { Sub-sample } 3 \text { - } \\
\text { Beverage }\end{array}$ \\
\hline Constant & $0.0272(1.59)$ & $0.0303(1.86)$ & $0.0564(1.05)$ & $0.0451(4.47)$ \\
\hline $\mathrm{D}$ & $0.0103(0.46)$ & $0.0113(0.55)$ & $0.0737(1.09)$ & $-0.0013(-0.10)$ \\
\hline $\mathrm{RxD}$ & $0.1542 *(1.78)$ & $0.1905 *(1.94)$ & $0.6746^{* * *(3.109)}$ & $0.0842 * *(1.81)$ \\
\hline Obs & 308 & 183 & 45 & 63 \\
\hline R-squared & 0.0221 & 0.0333 & 0.2550 & 0.0621 \\
\hline Adj R-squared & 0.0124 & 0.0171 & 0.2005 & 0.0145 \\
\hline F-Statistics & $2.29 *$ & $2.05 *$ & $4.68 * *$ & $1.30 *$ \\
\hline
\end{tabular}

Notes: (1) E refers to the earnings per share divided by the stock price for firm i accumulated over the period $t-1$ to $t$.

Rit is a twelve-month stock return that indicates the return on the share in period $t$ by accumulating the price differentials

of the 12 months in period t, Di is a dummy variable assuming the value of one if stock return (R) is negative and equals zero otherwise. * Significant at the $10 \%$ level. $* *$ Significant at the $5 \%$ level. *** Significant at the $1 \%$ level

Table VII - Regression results on smoothers and non-smoothers samples

\begin{tabular}{lrr}
\hline Variable & \multicolumn{1}{c}{$\begin{array}{c}\text { Sample of } \\
\text { Non-Income Smoothing }\end{array}$} & \multicolumn{1}{c}{$\begin{array}{c}\text { Sample of } \\
\text { Income Smoothing }\end{array}$} \\
\hline Constant & $0.0348(1.21)$ & $0.0234(1.01)$ \\
R & $0.0011(0.01)$ & $-0.0565(-0.56)$ \\
D & $0.0297(0.82)$ & $-0.0023(-0.08)$ \\
RxD & $0.2772 * *(2.04)$ & $0.1016(0.83)$ \\
Obs & & 178 \\
R-squared & 0.0773 & 0.0044 \\
Adj R-squared & 0.0534 & -0.0128 \\
F-Statistics & $3.24 * *$ & 0.25 \\
\hline
\end{tabular}




\section{Appendix A - Correlation matrices}

Total Sample

\begin{tabular}{lrrrr}
\hline & $\mathrm{E}$ & $\mathrm{R}$ & $\mathrm{D}$ & $\mathrm{RxD}$ \\
\hline & & & & \\
$\mathrm{E}$ & 1.0000 & & & \\
$\mathrm{R}$ & 0.1022 & 1.0000 & & \\
$\mathrm{D}$ & -0.0442 & -0.6983 & 1.0000 & \\
$\mathrm{RxD}$ & 0.1413 & 0.8586 & -0.5584 & 1.0000 \\
\hline
\end{tabular}

Sub-sample 1 - Food Manufacturing

\begin{tabular}{lrrrr}
\hline & $\mathrm{E}$ & $\mathrm{R}$ & $\mathrm{D}$ & $\mathrm{RxD}$ \\
\hline & & & & \\
$\mathrm{E}$ & 1.0000 & & & \\
$\mathrm{R}$ & 0.0733 & 1.0000 & & \\
$\mathrm{D}$ & 0.014 & -0.6795 & 1.0000 & \\
$\mathrm{RxD}$ & 0.1321 & 0.9163 & -0.5348 & 1.0000 \\
\hline
\end{tabular}

Sub-sample 2 - Food Retailing

\begin{tabular}{lrrrr}
\hline & $\mathrm{E}$ & $\mathrm{R}$ & $\mathrm{D}$ & $\mathrm{RxD}$ \\
\hline & & & & \\
$\mathrm{E}$ & 1.0000 & & & \\
$\mathrm{R}$ & 0.2335 & 1.0000 & & \\
$\mathrm{D}$ & -0.0647 & -0.743 & 1.0000 & \\
$\mathrm{RxD}$ & 0.4438 & 0.7898 & -0.5717 & 1.0000 \\
\hline
\end{tabular}

Sub-sample 3 - Beverage

\begin{tabular}{llll}
\hline $\mathrm{E}$ & $\mathrm{R}$ & $\mathrm{D}$ & $\mathrm{RxD}$ \\
\hline
\end{tabular}

\begin{tabular}{lrrrr}
$\mathrm{E}$ & 1.0000 & & & \\
$\mathrm{R}$ & 0.0952 & 1.0000 & & \\
$\mathrm{D}$ & -0.0895 & -0.7565 & 1.0000 & \\
$\mathrm{RxD}$ & 0.2117 & 0.8115 & -0.6379 & 1.0000 \\
\hline
\end{tabular}

Sample - Companies NON-Income Smoothing

\begin{tabular}{lrrrr}
\hline & $\mathrm{E}$ & $\mathrm{R}$ & $\mathrm{D}$ & $\mathrm{RxD}$ \\
\hline & & & & \\
$\mathrm{E}$ & 1.0000 & & & \\
$\mathrm{R}$ & 0.1914 & 1.0000 & & \\
$\mathrm{D}$ & -0.0803 & -0.7319 & 1.0000 & \\
$\mathrm{RxD}$ & 0.2639 & 0.8272 & -0.5755 & 1.0000 \\
\hline
\end{tabular}


Sample-Companies Income Smoothing

\begin{tabular}{lrrrr}
\hline & $\mathrm{E}$ & $\mathrm{R}$ & $\mathrm{D}$ & $\mathrm{RxD}$ \\
\hline & & & & \\
$\mathrm{E}$ & 1.0000 & & & \\
$\mathrm{R}$ & 0.0206 & 1.0000 & & \\
$\mathrm{D}$ & -0.0115 & -0.6718 & 1.0000 & \\
$\mathrm{RxD}$ & 0.048 & 0.8784 & -0.5399 & 1.0000 \\
\hline
\end{tabular}

14

15

16

17 


\title{
Accounting Conservatism and Income Smoothing Practices in the EU Food and Drink Industry
}

\begin{abstract}
Purpose: The purpose of this paper is to identify the application of the fundamental principle of accounting conservatism within the EU food and drink industry. Furthermore, we also investigate in depth this conservatism in two different sub-samples (income smoothers and non-income smoothers). Design/methodology/approach: All EU-listed companies in the food and drink industry were identified covering the year 2019. Basu's model was adopted to test the degree of conditional conservatism, while Eckel's model was used to classify listed companies as smoothing or nonsmoothing.
\end{abstract}

Findings: The results indicate that conservatism is strongly present in the food and drink industry and also in its sub-industries. We also showed that non-smoothing firms had higher levels of conditional conservatism in terms of more opportunity to recognize future economic losses because the market could use the stock return data to anticipate future losses contained in the information regarding profits.

Research limitations/implications: One limitation of this work is the small size of the investigated companies. We demonstrate that the likely increased use of conservatism produces a better credibility in the EU markets. Practical implications indicate a higher degree of monitoring of the accounting practices adopted by firms. Regulators have to set accounting policies to enhance the quality of the informational environment, investors and shareholders might exercise control over executives' decisions, and lenders might impose contractual clauses requiring the timely disclosure of 'bad news.' Originality/value: This industry is "belted" from any external speculations. This research also made it possible to observe the theoretical relationships between smoothers and non-smoothers as shown in the financial information provided by the EU food and drink industry.

Keywords: food and drink industry, accounting conservatism, income smoothing Paper type: research paper 


\section{Introduction}

Accounting conservatism is a fundamental attribute that is closely linked to the market. According to Basu (1997), conservatism is defined as "the tendency to require a higher degree of verification to recognize good news as gains than to recognize bad news as losses" and as showing the asymmetrical verification requirements for gains and losses. Therefore, conservatism means having higher verification requirements for losses than gains. Regulators, standard setters, and firms have defined conservatism as the accounting process that is likely to understate net assets and cumulative income (Kieso et al., 2004; Revsine et al.,1999).

The purpose of this paper is to test the conditional accounting conservatism of EU-listed firms which operate in the EU food and drink sector for the reason that it represents the main domestic industry in all European countries (Abdel-Kader \& Luther, 2006). This industry is the EU's biggest manufacturing sector in terms of added value. In the last 10 years, EU food and drink exports have duplicated, achieving over EUR 90 billion and contributing to a positive balance of almost EUR 30 billion (EU Commission, 2020). According to Mann et al. (1999b), this sector is also the largest in terms of employment for over three million people from primary producers to manufacturers and retailers. EU food and drink regulation is strongly harmonised, and the industry can benefit from the opportunities offered by the EU single market. At the same time, however, the sector faces certain challenges in both international and European markets. There is also a need for an increased emphasis within the industry and its full supply chain network on the broader social and economic impacts of food and drink production, distribution, purchasing, and consumption. This industry is the driving force behind EU exports and commands a very good reputation globally. The above data demonstrate that this is a dominant industry as well as a useful context for investigation in this research.

We verified whether such a relevant industry is "protected" by accounting rules and whether the quality of earnings is in line with the market price. In addition, we also examine the above relationship by distinguishing two samples: first, companies that adopt income smoothing practices and second, those that do not. The results demonstrate the hypothesis that EU-listed firms avoid the use of any earnings management practices and that they have a greater ability to recognize future economic losses. In other words, the EU food and drink industry is considered "safeguarded" because the application of conservatism in earning recognition is associated with real companies' values. We also found that the more companies employ income smoothing (i.e., adopt accruals to reduce the variability of profits), the greater the possibility there is for the timely acknowledgement of future economic losses.

This study bases its accounting conservative on "timely loss recognition" as formulated by Basu (1997) in which earnings are regressed on the negative returns (as a proxy of "bad news"), the interaction variable of negative returns (proxied by a dummy variable), and the returns themselves.

This study demonstrates a need for leading managers to provide further accounting disclosures to enhance the credibility of financial statements. Moreover, there must be several steps towards developing corporate governance mechanisms that will protect the investors' and shareholders' interests.

Implications from this research are based on greater monitoring of the accounting practices adopted by firms. The research can also generate a direct benefit to investors in the food and drink industry through earlier recognition of losses in the income statement which, as a result, can generate greater market confidence. This empirical evidence suggests that the elimination of conservatism from accounting regulatory frameworks may lead to undesirable economic consequences in the EU context within the largest industry sector. Regulators might set accounting policies to enhance the quality of the informational environment; on the other hand, investors and shareholders might control executives' decisions, and finally, lenders might impose contractual clauses requiring the timely disclosure of 'bad news.' 
To the authors' knowledge, this represents the first work that examines the characteristics and the determinants of accounting conservatism at the EU level in this type of industry.

The rest of the paper is articulated as follows: in the second section, we present the economic data for the EU food industry over recent years that justifies the importance of such sector in terms of value creation and jobs. In the third section, we present the prior studies on accounting conservatism together with the hypotheses developed. The fourth section reports our data collection process, the sample, and the methodology by which the statistical analysis is performed. The fifth section presents the descriptive statistics and the findings. Finally, the sixth section discusses the results and shows the contribution, implications, and limitations of the study.

\section{Theoretical Backgrounds and Prior Studies}

\subsection{Accounting Conservatism}

The conservatism principle has been studied since the fifteenth century, pre-dating Pacioli's treatise on accounting bookkeeping (Andrè et al., 2015). Empirical research into accounting conservatism has prospered over the last two decades in different countries and industries. Accounting conservatism is considered one of the most important properties of financial reporting, indispensable for mitigating agency costs and inseparable from accounting standards (Zhong \& Li, 2017). Givoly and Hayn (2000) pointed out that conservatism is the selection criterion between accounting principles that leads to the minimization of cumulative reported earnings and net assets through lower revenue recognition and lower asset valuation. According to Kieso et al. (2004) and Revsine et al. (2005), conservatism is the accounting process that is likely to understate net assets and cumulative income. According to Dickhaut et al. (2010), conservatism avoids the overstatement of net assets and income, limiting actions of earnings manipulation. Sugiarto and Fachrurrozie (2018) found that financially distressed companies are more likely to employ accounting conservatism, while managerial ownership has a significantly negative effect on accounting conservatism. Conservatism improves investment efficiency (Lara et al., 2016) and resolves debt-equity conflicts, facilitating companies' access to debt financing.

Balachandran and Mohanram (2011, p. 275) discussed conservatism as "the downward bias in book values relative to market" values (Beaver \& Ryan 2000) or "downward bias because of specific accounting practices" (Penman \& Zhang 2002).

The debate within international doctrine over accounting conservatism is based on two types of conservatism: unconditional conservatism and conditional conservatism (Beaver \& Ryan, 2005; Nasev, 2009). Under unconditional conservatism, the book value of net assets is understated due to predetermined aspects of the accounting process (Beaver \& Ryan, 2005) and is not conditioned on the economic reality (Jenkins et al., 2009). Write-off items do correspond to accounting policies as proxied by the period of the asset, as the recognition of depreciation expense of an asset over eight years instead of 10 years is likely to lower current earnings.

Conditional conservatism refers to reporting accounting numbers that are conditional on the firm experiencing contemporaneous economic loss. It therefore captures the timely recognition of accounting loss. Conditional conservatism has affected accounting policies and represents one of the most fundamental pillars in accounting and reporting (Watts, 2003).

However, the International Accounting Standards Board (IASB) has been issuing a strong push for the "fair value" accounting that essentially represents the opposite of conditional conservatism requiring symmetric timeliness: the recognition of 'good news' is not postponed so that 
both good news and bad news are accounted for (Kim \& Pevzner, 2010). Conditional conservatism only demands deferred recognition of 'good news.'

Ball and Shivakumar (2005, p. 91) state that "while unconditional conservatism seems inefficient or at best neutral in contracting, conditional conservatism (timely loss recognition) can enhance contracting efficiency."

Accounting conservatism has been studied in different industry sectors which provide a large array of empirical results. Easton and Pae (2004) found that accounting in the pharmaceutical industry is more conservative than accounting for other industries. Empirical evidence has also provided a higher level of accounting conservatism in high-tech firms (Kwon et al., 2006). Enache and García-Meca (2019) focused on biotechnological companies and found that companies with more outside members are likely to demand more conservative accounting. Zhang (2020) found that accounting conservatism prevails in the insurance industry. Santi et al. (2017) found that unconditional conservatism has a positive influence on earnings quality upon IFRS convergence in manufacturing companies. Also, banking industries represented a context where accounting conservatism was tested (Leventis et al., 2013; Kanagaretnam et al., 2014; Lim et al., 2014). Finally, the food and beverage industry has been discussed in light of several contributions in accounting conservatism research (Jacob, 2019; Oyedokun \& Salisu, 2018; Suleiman \& Anifowose, 2014).

In this paper, the focus is on conditional conservatism, meaning the timely recognition of economic losses in the EU food and drink industry. We selected this industry given its importance for having represented the world's largest EU industry contributing to the wealth development of countries. In line with prior studies, we seek to test the following hypothesis:

$H_{l a} \rightarrow$ Companies with higher conditional conservatism accounting practices are likely to have higher market values in the EU food \& drink industry.

\subsection{Income smoothing}

The practice of income smoothing has a long tradition in accounting and corporate finance. Acharya and Lambrecht (2015) point out that a primary reason for companies becoming involved in income smoothing practices is the pressure imposed on managers to meet the market's earnings expectations.

Bao and Bao (2004) explained the successful research impact of income smoothing. Income smoothing is a form of earnings management that has been more successful than the study of other forms for two reasons: first, income smoothing has been defined more precisely, ${ }^{1}$ and second, the differentiation between 'smoothers' and 'non-smoothers' has been operationalized successfully in many studies (Bao \& Bao, 2004; Belkaoui \& Picur, 1984; Michelson et al., 1995, 2000).

Companies usually adopt this technique because investors are quite willing to pay a premium for a stock with steady and predictable earnings streams as opposed to stocks whose earnings are subject to more volatile patterns. According to Beidleman (1973, p. 653), income smoothing is related to the "dampening of fluctuations about some level of earnings that is currently considered to be normal for a firm." More recently, Baik et al. (2020) found that managerial ability is positively related to smoothing as well as high-ability managers incorporate more forward-looking information about cash flows into current earnings through smoothing, thereby enhancing earnings informativeness.

Above all, there is one main reason that leads companies into smoothing the earnings of the economic unit, and it is based on investor confidence improvement: specifically, economic unity is

\footnotetext{
${ }^{1}$ Fudenberg and Tirole (1995, p. 75) provided a specific definition: income smoothing is "the process of manipulating the time profile of earnings or earnings reports to make the reported income stream less variable, while not increasing reported earnings over the long run."
} 
achieved through stable earnings as well as stability of earnings per share. In turn, this stability produces higher market values and, thus, higher interest from potential investors by maximizing their wealth and enhancing their confidence in economic units (Steven \& Yoonseok, 2009).

Income smoothing can be intentional or natural (Albrecht \& Richardson, 1990). Intentional smoothing can be set by timing real business decisions (real smoothing) or by selecting accounting policies that allocate earnings over time in the desired manner (artificial smoothing). On the other hand, natural practices include mechanisms of the accrual process that management does not manipulate (Gassen et al., 2006). Some scholars (Dechow \& Skinner, 2000; Fudenberg \& Tirole, 1995) argue that artificial income smoothing is a form of earnings management and represents earnings manipulation through the accrual process to make the earnings flow in a less fluctuating manner while not increasing or decreasing equity in the long term. By representing a discretionary attribute of earnings, income smoothing provides data for the capital markets, and rational investors may not be misled by this practice since returns (economic earnings) and cash flows (cash earnings) are observable. Income smoothing can provide a signal (Barnea et al., 1976) that in case it is verifiable and management owns private information about earnings in the future, this practices represents a vehicle to publicly communicate this information. On the contrary, if the signal is not verifiable, income smoothing is ignored by market participants.

\subsection{The relationship between income smoothing and accounting conservatism}

Conservatism and income smoothing are properties of accounting information that are strongly associated with and impact the earnings quality. Conditional conservatism and income smoothing represent two main elements that can strongly affect the quality of the financial information that is communicated to the market (Ryan, 2006). Both of these properties, conservatism and smoothing, can result in a reduction of optimism, and smoothing can interfere with a firm's capacity to recognize bad economic news (i.e., economic losses) (Almeida et al., 2012). A very recent contribution by Lara et al. (2020) analyzed the impact of conditional conservatism on earnings management - the broader area of income smoothing. They supported the view that conditional conservatism has the ability to alleviate accruals-based earnings management. Chen et al. (2007) studied the role of conservative accounting standards in reducing rational yet dysfunctional unobservable earnings manipulation. Eddie and Yamaguchi (2018) examined the change in accounting conservatism following the Japanese Serbanes Oxley Act that aimed to evaluate internal control systems relating to financial reporting and demonstrate an increase in accounting conservatism in the post-J-SOX period. Also Delkhosh and Sadeghi (2017) recently investigated the role of conservatism and earnings quality, discovering a significant and negative impact of accounting conservatism and earnings management on the quality of earnings. Gassen et al. (2006) state that conditional conservatism is positively associated with the degree of indebtedness of firms, as income smoothing affects firms' dividend policies. The results support the theoretical claim that smoothing interferes with a firm's capacity to recognize bad economic news (i.e., economic losses). The reduction of optimism from the market represents the result of income smoothing practices that are intended to prevent profits from appearing to be too far above or below market expectations. Thus, conservatism and smoothing can result in a reduction of optimism. On the other hand, companies that have no experience in income smoothing practices are seen with much optimism, and thus their accounting conservatism indicates a high-quality level of earnings. From here stems the second main hypothesis to be tested:

$H_{1 b} \rightarrow$ Companies that have not experienced income smoothing practices are likely to have a strong level of conditional conservatism accounting practices in the EU food and drink industry. 


\section{Research method}

\subsection{EU economic bulleting of the food and drinks industry}

The food and drink sector represents the world's largest manufacturing industry and is an integral part of the world's social, economic, and cultural values contributing to the wealth development of countries. During the period of economic crisis in 2008-2014, turnover grew by almost $7 \%$ while turnover in the overall manufacturing industry decreased by $0.8 \%$ (FoodDrinkEurope, 2016).

In 2016, as reported by the graph, total turnover and share of employment of the EU food and drink industry was weighted at $15.1 \%$ and $15.5 \%$, respectively, to the total EU manufacturing industry representing the EU's largest industry in terms of turnover and jobs.

Figure 1. Share of turnover in the EU manufacturing industry (2016, \%). Source: FoodDrinkEurope (2019)

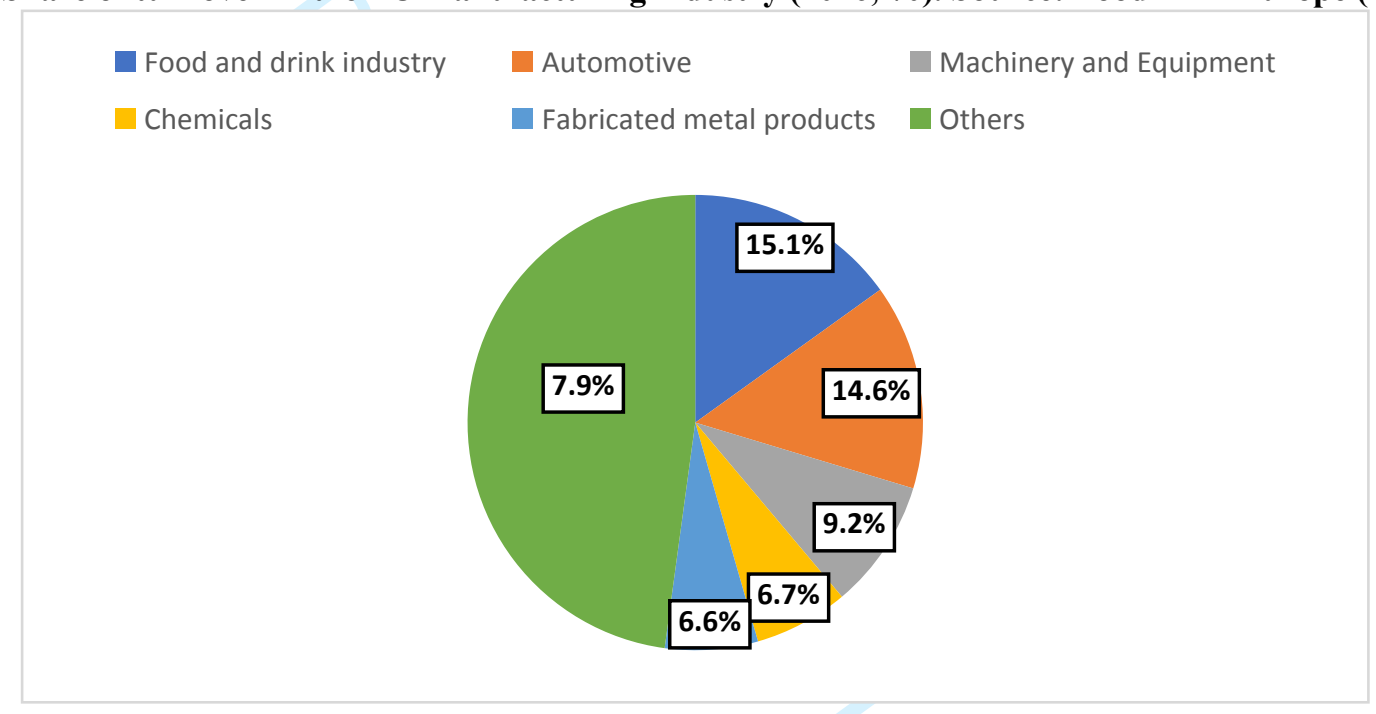

Figure 2. Share of employment in the EU manufacturing industry (2016, \%). Source: FoodDrinkEurope (2019)

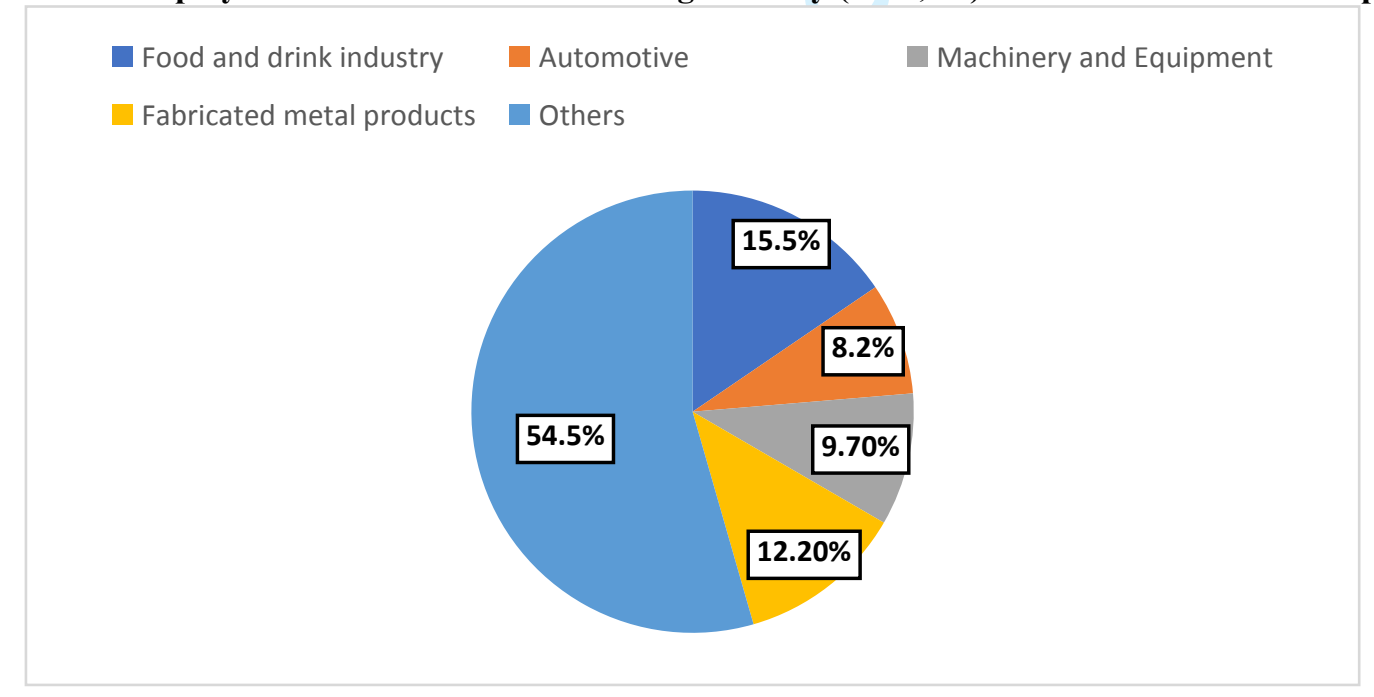

In 2019, the EU food and drink industry included 294,000 companies and employed 4.72 million workers for a total turnover of 1.192 billion euros representing the largest EU manufacturing industry. In 2019, the trade showed $€ 110$ billion in exports and $€ 74$ billion in imports with a trade balance of $€ 36$ billion (FoodDrinkEurope, 2019). 
Compared to non-EU countries, 10 nations out of 15 in the top markets are based in Europe as showed by the graph below with the largest markets for exports of food and drinks in 2019 .

Figure 3. Top markets in the food and drink industry (data in $\mathfrak{f} /$ million). Source: FDEA (Food and Drink Exporters Association, 2019). Retrived from https://www.fdf.org.uk/corporate_pubs/FDF-Industry-Report2020.pdf

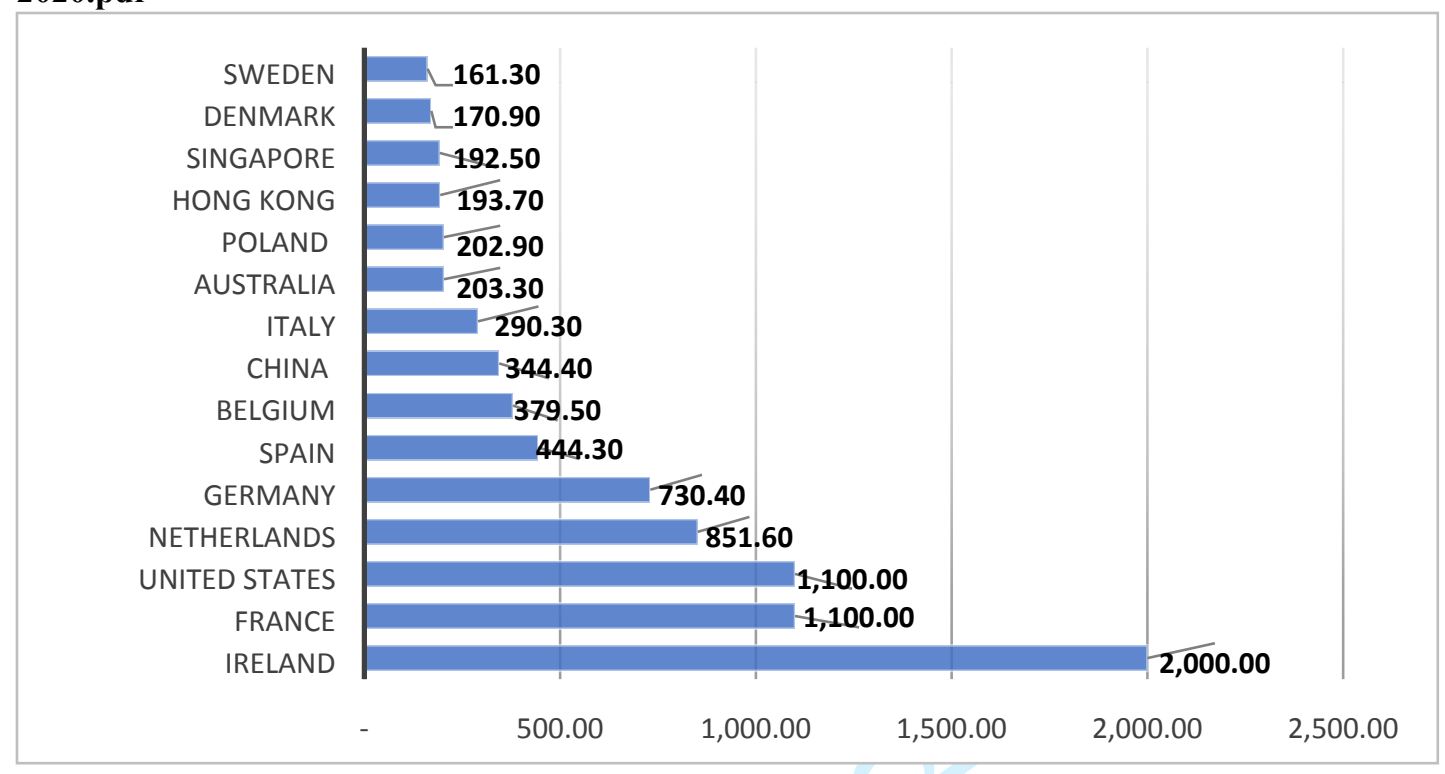

In the first quarter of $2020, \mathrm{EU}$ food and drink industry production increased by $0.4 \%$ compared to the previous quarter, and turnover increased by $2.8 \%$ compared to the previous quarter (FoodDrinkEurope, 2020).

The year-on-year comparison shows that food and drink industry production growth exceeded total manufacturing production growth $(0.2 \%$ vs. $-4.9 \%$ compared to the first quarter of 2019$)$. The year-on-year growth in food and drink industry turnover exceeded that of all manufacturing industries (5.4\% vs. $-4.7 \%$ compared to the first quarter of 2019). The turnover in the food and drinks segment is projected to reach $€ 17,668 \mathrm{~m}$ in 2020 .

Figure 4. Forecasted total turnover in the food and drink segment ( $€$ /million). Source: Statista (forecast adjusted for expected impact of COVID-19. August 2020. 


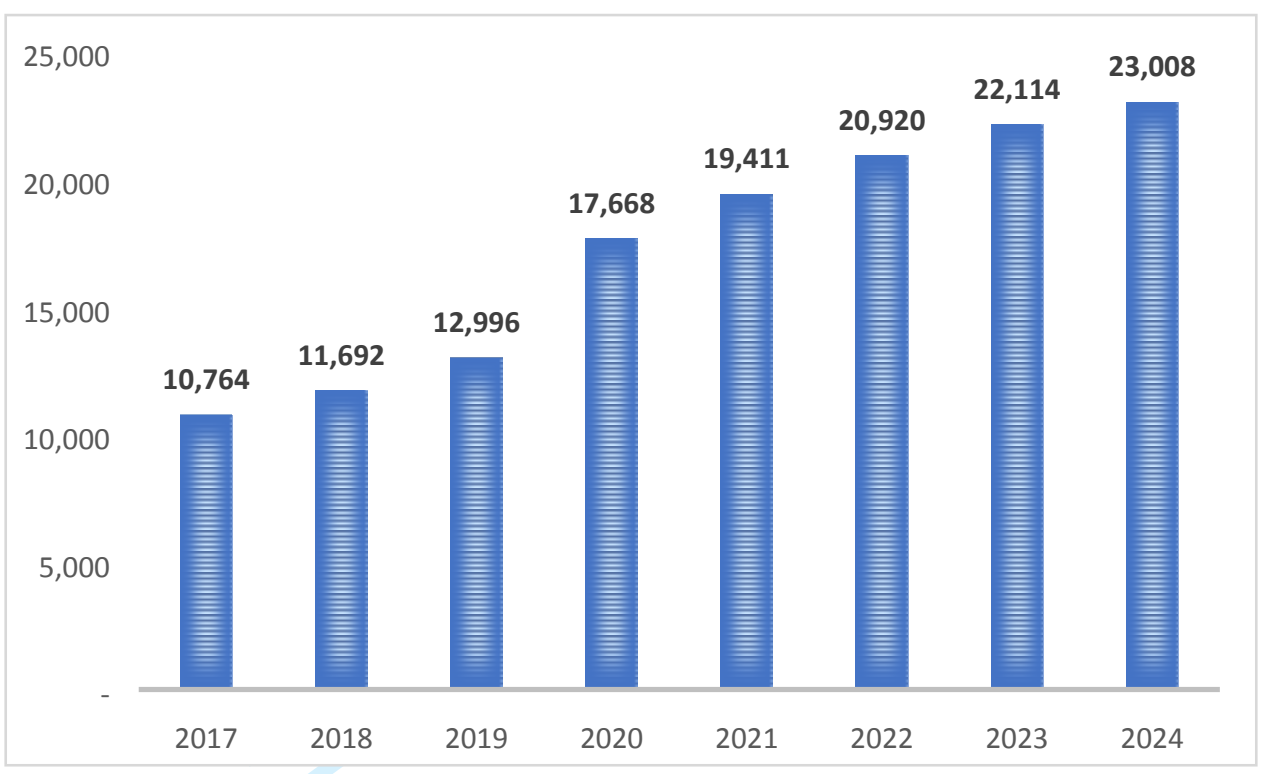

Furthermore, it is also expected to show a revenue growth of $9.9 \%$ in 2021.

Figure 5. Forecasted trend (\%) of total turnover in the food and drink segment. Source: Statista (forecast adjusted for expected impact of COVID-19). August 2020.

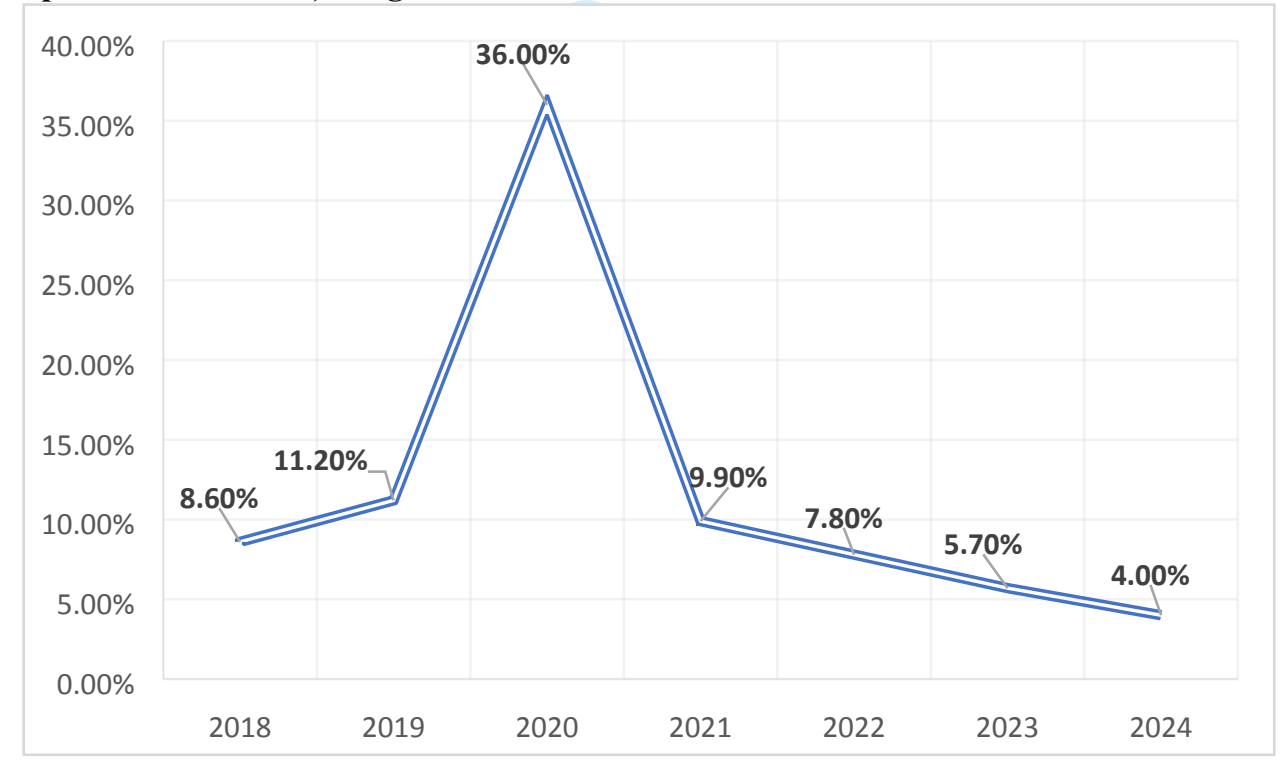

\subsection{Sampling process}

From the original data of 358 observations, 50 companies were excluded because of missing data so that the final sample was composed of 308 EU-listed companies currently operating in the EU food and drink main sector which includes the following sub-industries: food manufacturers, food retailers, and beverage. Those companies are all IFRS adopters for which data analysis is based on consolidated financial statements covering the most recent annual year of 2019. We construct the Basu's conditional accounting conservatism measure based on data collection from Thomson Reuters, one of the most widely used for the analysis of accounting and market data. All data have been inserted in the statistical processing software (STATA) to estimate through the method of OLS regression the coefficients and obtain the results that are described and commented on in the next section. 
Subsequently, we compared the degree of conservatism among the groups of EU-listed companies that either smooth or do not smooth results applying Eckel's model as explained in Section 4.2 .

From the full sample of 308 companies, the observations needed to classify the companies into smoothers and non-smoothers were extracted, distinguishing between 120 non-income smoothers and 178 income smoothers (10 companies belong to the grey area). In classifying companies into smoothers and non-smoothers, we normalized the variables in Basu's model (1997) to exclude observations greater than three standard deviations from the mean.

Table 1. Sampling process.

\begin{tabular}{lr}
\hline Data from Thomson Reuters & Number of observations \\
\hline EU-listed companies in Food \& Drink & 358 \\
Companies not included because of missing data & 50 \\
Companies sampled & 308 \\
$\%$ coverage & $88 \%$ \\
\hline
\end{tabular}

Table 2. Sub-industry observations.

\begin{tabular}{lr} 
& Total sample \\
\hline Food Manufacturing & 187 \\
Food Retailing & 45 \\
Beverage & 76 \\
Total & 308 \\
\hline
\end{tabular}

Table 3. Country analysis.

\begin{tabular}{|c|c|c|c|c|c|}
\hline Austria & 4 & $1.30 \%$ & Latvia & 2 & $0.65 \%$ \\
\hline Belgium & 12 & $3.90 \%$ & Lithuania & 6 & $1.95 \%$ \\
\hline Bulgaria & 6 & $1.95 \%$ & Luxembourg & 6 & $1.95 \%$ \\
\hline Croatia & 11 & $3.57 \%$ & Malta & 1 & $0.32 \%$ \\
\hline Cyprus & 7 & $2.27 \%$ & Netherlands & 10 & $3.25 \%$ \\
\hline Czech Republic & 1 & $0.32 \%$ & Norway & 11 & $3.57 \%$ \\
\hline Denmark & 5 & $1.62 \%$ & Poland & 22 & $7.14 \%$ \\
\hline Estonia & 3 & $0.97 \%$ & Portugal & 3 & $0.97 \%$ \\
\hline Faroe Island & 1 & $0.32 \%$ & Rep of Serbia & 6 & $1.95 \%$ \\
\hline Finland & 8 & $2.60 \%$ & Romania & 11 & $3.57 \%$ \\
\hline France & 28 & $9.09 \%$ & Russia & 10 & $3.25 \%$ \\
\hline Germany & 24 & $7.79 \%$ & Slovenia & 3 & $0.97 \%$ \\
\hline Greece & 12 & $3.90 \%$ & Spain & 7 & $2.27 \%$ \\
\hline Hungary & 2 & $0.65 \%$ & Sweden & 14 & $4.55 \%$ \\
\hline Island & 4 & $1.30 \%$ & Switzerland & 9 & $2.92 \%$ \\
\hline Ireland & 7 & $2.27 \%$ & Ukraine & 5 & $1.62 \%$ \\
\hline \multirow[t]{2}{*}{ Italy } & 11 & $3.57 \%$ & United Kingdom & 36 & $11.69 \%$ \\
\hline & & & Total & 308 & $100.00 \%$ \\
\hline
\end{tabular}

\subsection{Model specification}

Our analysis uses Basu's (1997) model to test the conservatism principle concerning earnings that capture bad news faster than good news, also called timely loss recognition. Basu stated that 
conservatism relies on "capturing accountants' tendency to require a higher degree of verification for recognizing good news than bad news in financial statements" (Basu, 1997).

Adopting stock returns to measure between good and bad news, we expected that in a reverse regression of earnings on stock returns, a higher association of earnings with negative stock returns than with positive stock returns would be observed (Amran \& Abdul Manaf, 2014).

Consistent with prior research (Andrè et al., 2015), the asymmetric treatment of losses and gains is captured by the piecewise-linear regression of accounting earnings on stock returns:

$$
E_{t}=\beta_{0}+\beta_{1} D_{i}+\beta_{2} R_{i t}+\beta_{3} D_{i} * R_{i t}+\varepsilon_{i, t}(1)
$$

where $E_{t}$ is annual net income per share after taxes and before extraordinary items lagged by the market value per share at beginning of period ( $\mathrm{t}-1) ; R_{i t}$ is a twelve-month stock return that indicates the return on the share in period $t$ by accumulating the price differentials of the 12 months in period $t ; D_{i}$ is a dummy variable assuming the value of one if stock return $(R)$ is negative and equals zero otherwise; and $\varepsilon_{i, t}$ is the residual term. According to the model, timely loss recognition supports the principle of prudence that negative returns are recognized faster than positive returns. Therefore, the higher the value of the coefficient associated with $\beta 3$, the greater the positive relationship between the application of conservatism and the value relevance. The coefficient $\beta 3$ indicates the sensitivity of earnings to negative stock returns, and it is expected to be positive and significant when earnings are more sensitive to negative stock returns than to positive stock returns.

In order to test the model in two different samples (companies which adopt income smoothing or not), we used Eckel's model (1981) based on the assumption that revenues and expenses are linear over time meaning that they grow or decline at the same rate. According to Eckel (1981) and Leuz et al. (2003), when a linear relationship between revenues and sales is not observed, this property may be due to interference from executives to smooth the results.

To test the relationship between profits and revenues, the coefficients of the percentage variations of net income and sales revenue are computed. In case the coefficient of the net earnings is less than that of the revenue, this shows that the company is interfering in the profits through artificial smoothing, as reported below:

$$
0.9 \leq \frac{C V \Delta \% \text { Net Income }}{C V \Delta \% \text { Sales }} \leq 1.1
$$

where:

$\mathrm{CV} \Delta \%$ Net Profit $=\left(\right.$ Net Profit $_{t}-$ Net Profit $\left._{\mathrm{t}-1}\right) /$ Net Profit $_{\mathrm{t}-1}$;

$\mathrm{CV} \Delta \%$ Sales $=\left(\right.$ Revenue $_{\mathrm{t}}-$ Revenue $\left._{\mathrm{t}-1}\right) /$ Revenue $_{\mathrm{t}-1}$; and

$\mathrm{CV} \Delta \%$ Net Profit $\leq \mathrm{CV} \Delta \%$ Sales $=$ Income Smoothing.

This indicates that if the ratio's result is less than 0.9 , the company performs income smoothing; on the other hand, if the ratio is higher than 1.1, the company does not perform income smoothing. This method allows for the objective classification of selected companies, thus decreasing risk of bias. The companies that record results within that range (from 0.9 to 1.1 ) were excluded, as shown by the processing of the sample shown in Table 4.

Table 4. Samples of income smoothing and non-income smoothing.

\begin{tabular}{rr}
\hline & Companies selected \\
\hline Non-income smoothing & 120 \\
Income smoothing & 178
\end{tabular}




\section{Findings}

\subsection{Descriptive statistics}

Table 5 presents the descriptive statistics for the variables used in our model. The mean value of net earnings hare adjusted by the stock price at the beginning of the firm year is 0.015 , and the minimum value is -0.970 while the maximum value is 0.430 . The twelve-month stock return that indicates the return on the share in period $t$ by accumulating the price differentials of the 12 months in period $t$ shows an average value of -0.0745 and a minimum value of -0.910 , while the maximum value is 0.780 . The number of observations for all variables is 308 , meaning there are no missing values. Correlation matrices (not reported) have been computed too with respect to sub-industries of food and drink.

Table 5. Descriptive data.

\begin{tabular}{lrrrrr}
\hline Variable & Obs & Mean & Std. Dev. & Min & Max \\
\hline & & & & & \\
E & 308 & 0.0154 & 0.1320 & -0.97 & 0.43 \\
R & 308 & -0.0745 & 0.2489 & -0.91 & 0.78 \\
D & 308 & 0.6591 & 0.4748 & 0 & 1 \\
RxD & 308 & -0.1314 & 0.1695 & -0.91 & 0 \\
\hline
\end{tabular}

\begin{tabular}{lll}
\hline Dummy & Obs & $\%$ \\
\hline $\mathrm{D}=1$ & 203 & $65.9 \%$ \\
$\mathrm{D}=0$ & 105 & $34.1 \%$ \\
& 308 & $100 \%$ \\
\hline
\end{tabular}

\subsection{Regression results}

Table 6 discloses the output of the regression model with interaction terms that we used to test our research hypothesis. Table 6 (Panel A - Total Sample) shows no statistical significance for the variables $R$ and $D$ while the interaction term $(R \times D)$ is positive $(0.1542)$ and statistically significant at $10 \%$. Results from the total sample show that timely loss recognition supports the principle of prudence that negative returns are recognized faster than positive returns. The variable $\mathrm{RxD}$ is found to be positively $(+0.1542)$ and statistically significant (P-value at $10 \%$ level) to the market values. The coefficient of $\mathrm{RxD}$ on the market return measures the timeliness of gain recognition or the responsiveness of earnings to good news, while the sum of $\beta_{2}+\beta_{3}$ measures the timeliness of loss recognition or the responsiveness of earnings to bad news. As reported by Pope and Walker (1999), the $\beta_{3}$ coefficient $(+0.1542)$ measures incremental timeliness of loss recognition. We found a positive and significant coefficient $\beta_{3}$ that implies asymmetric timely loss recognition and therefore conditional conservative accounting (Pope \& Walker, 1999; Ball et al., 2000). 
This can lead to the interpretation which states that the higher the value of $\mathrm{RxD}$, the greater the positive relationship between the application of conservatism and the value relevance. $\mathrm{RxD}$ demonstrates a positive sensitivity of earnings to negative stock returns.

Table 6. Regression results on total sample and sub-samples.

\begin{tabular}{|c|c|c|c|c|}
\hline Variable & Total Sample & $\begin{array}{c}\text { Sub-Sample } 1 \text { - } \\
\text { Food Manufacturing }\end{array}$ & $\begin{array}{l}\text { Sub-Sample } 2 \text { - } \\
\text { Food Retailing }\end{array}$ & $\begin{array}{c}\text { Sub-Sample } 3 \text { - } \\
\text { Beverage }\end{array}$ \\
\hline Constant & $0.0272(1.59)$ & $0.0303(1.86)$ & $0.0564(1.05)$ & $0.0451(4.47)$ \\
\hline $\mathrm{R}$ & $0.0478(-1.20)$ & $0.0536(1.28)$ & $0.1123(1.05)$ & $0.0211(1.66)$ \\
\hline $\mathrm{D}$ & $0.0103(0.46)$ & $0.0113(0.55)$ & 0.0737 (1.09) & $-0.0013(-0.10)$ \\
\hline $\mathrm{RxD}$ & $0.1542 *(1.78)$ & $0.1905 *(1.94)$ & $0.6746 * * *(3.109)$ & $0.0842 * *(1.81)$ \\
\hline Obs & 308 & 183 & 45 & 63 \\
\hline R-squared & 0.0221 & 0.0333 & 0.2550 & 0.0621 \\
\hline Adj R-squared & 0.0124 & 0.0171 & 0.2005 & 0.0145 \\
\hline F-statistics & $2.29 *$ & $2.05^{*}$ & $4.68 * *$ & $1.30 *$ \\
\hline \multicolumn{5}{|c|}{$\begin{array}{l}\text { Notes: (1) E refers to the earnings per share divided by the stock price for firm i accumulated over the period } \\
\mathrm{t}-1 \text { to } \mathrm{t} \text {. } \\
\mathrm{R}_{\mathrm{it}} \text { is a twelve-month stock return that indicates the return on the share in period } \mathrm{t} \text { by accumulating the price } \\
\text { differentials } \\
\text { of the } 12 \text { months in period } \mathrm{t}, \mathrm{D}_{\mathrm{i}} \text { is a dummy variable assuming the value of one if stock return }(\mathrm{R}) \text { is negative } \\
\text { and equals zero otherwise. } * \text { Significant at the } 10 \% \text { level. } * * \text { Significant at the } 5 \% \text { level. *** Significant at } \\
\text { the } 1 \% \text { level. }\end{array}$} \\
\hline
\end{tabular}

In addition, we also set as a robustness check three OLS regressions for the following sub-samples: food manufacturing, food retailing, and beverage. As observed in the above table, only the $\mathrm{RxD}$ is found to be positively and statistically significant in relation with market values for all the subsamples. This demonstrates that all sub-samples of food and drink still maintain the hypothesis developed for the general sample.

Table 7. Regression results on smoother and non-smoother samples.

\begin{tabular}{lrr}
\hline Variable & $\begin{array}{r}\text { Sample of } \\
\text { Non-Income Smoothing }\end{array}$ & $\begin{array}{r}\text { Sample of } \\
\text { Income Smoothing }\end{array}$ \\
\hline Constant & & \\
R & $0.0348(1.21)$ & $0.0234(1.01)$ \\
D & $0.0011(0.01)$ & $-0.0565(-0.56)$ \\
RxD & $0.0297(0.82)$ & $-0.0023(-0.08)$ \\
Obs & $0.2772^{* *}(2.04)$ & $0.1016(0.83)$ \\
R-squared & & 178 \\
Adj R-squared & 0.0773 & 0.0044 \\
F-statistics & 0.0534 & -0.0128 \\
\hline
\end{tabular}

Finally, we found that the classification of EU-listed companies in food and drink into groups of smoothers and non-smoothers based on Eckel's (1981) model justified the application of Basu's (1997) conditional conservatism model. In our case shown in the above table, for the sample of 


\section{Concluding remarks}

\subsection{Discussion}

The main objective of this paper was to report on the current state of the accounting conservatism principle - an important qualitative characteristic of financial reporting - in the EU food and drinks industry. This is intensely relevant given the motivation that EU food and drink represents the main domestic industry in all European countries (Abdel-Kader \& Luther, 2006), and it is the EU's biggest manufacturing sector in terms of value added.

We contribute to enlarging studies on accounting conservatism by finding that EU firms of food and drink have a greater ability to recognize future economic losses providing a high quality of accounts. In other words, they can be considered "safeguarded" because the application of conservatism in earnings recognition is associated with real companies' value. Furthermore, we have also assessed how the practice of non-smoothing of earnings can influence the conservatism.

The results from this study show that higher conservative practices will affect the informativeness of financial estimates increasing market credibility of the EU food and drink industry. In doing so, these findings can be considered as an outcome of the market assessment of disclosure credibility.

To make the results more robust, we have also included a further analysis distinguishing between companies that practice income smoothing activities and company that do not. We found a strong level of conservatism within companies that do not practice income smoothing that satisfy our hypothesis $1 b$.

Our results must be also taken considering the primary opportunities for food service and food retail industries to address their ESG issues which are not investigated in this paper but are no less important, such as reducing energy intensity of operations through efficiency efforts, enhancing recycling efforts of secondary or tertiary packaging waste, incorporating safety programs such as HACCP, encouraging vertically integrated firms (mostly grocery retailers) to improve the financial and environmental performance, and encouraging strategic alliances with suppliers.

Furthermore, some recommendations must be addressed. In general terms, the direction of the relationship between conservatism and value relevance is unclear, and it can be generalized since results from industries are different. Several scholars describe accounting treatments as "trade-offs" between relevance and reliability (Bandyopadhyay et al., 2009; Entwistle \& Phillips, 2003; Stanga, 1980). This can produce a disincentive for companies that are not willing to perform conditional accounting conservatism as stock returns cannot benefit from them. In addition, when the regulators are criticized, the critiques commonly portray regulations as having erred in the favor of one side at the expense of the other. The presumption behind the trade-off is that relevance decreases in conservatism. Therefore, the financial reporting council and other allied regulatory bodies must ensure clarity and provide rules with probably fewer discretionary tendencies for management to manipulate with the scope of enhancing the credibility of accounting data. 
We suggest that EU food and drink companies are successful when it comes to adopting new conservatism practices, although our study is neither longitudinal nor a comparative with other industries. For this reason, we are not able to confirm the conservatism principle to other sectors. Nevertheless, our results do provide detailed, large-scale data demonstrating the importance of the conservatism principle and its actual usage in the EU food and drink industry for future trends.

\subsection{Implications}

These results achieved within the food and drink sector point to different implications from both practical and theoretical perspectives. Practical implications are based on more monitoring activities by accounting regulators to enhance the quality of the informational environment.

Regulators' activities seem to be appropriate within our industry object of this analysis. Our analysis underlines the regulatory success of accounting standards and leads to the conclusion that regulators had developed rules that ensure the quality of accounting conservatism in the food and drink industry. However, accounting regulators must not radically change the structure and content of standards, but they must strengthen specific aspects of conditional conservatism.

In line with Mora and Walker (2015), conditional conservatism indicates when the asset value experiences an unexpected increase (or decrease) in its value then the firm must not recognize a gain (must record a loss). The IASB has to be much clearer on this specific aspect: do companies recognize all unrealized gains in the asset value in place under uncertainty? Do companies write up goodwill on acquisition if a merger turns out to be more successful than expected? A principle from the IASB conceptual framework is the neutrality indicating that companies must do it; on the other hand, conservatism establishes that companies should not. Standards setters should provide a guide on how and when conservatism or neutrality will be applied in cases where assets in place unexpectedly rise in value (Mora \& Walker, 2015).

Other practical implications refer to managers that can undertake real activities to achieve their financial reporting goals. There is a need for leading managers in the EU food and drink industry to provide further accounting disclosures to lend credibility in front of capital markets which contribute to providing inclusions to users of financial statements. In this context, investors might still control the managers' decisions, and lenders might impose contractual clauses requiring the timely disclosure of bad news. From the theoretical perspective, this paper implies that EU food and drink companies can benefit from more conservative financial reporting despite criticism regarding conservatism. In line with Zhong and Li (2017), to date, conservatism remains one of the most important properties of financial reporting that cannot be neglected and deserves further attention in research. Scholars can take the opportunity to better investigate conservatism in line with other nonfinancial aspects such as CSR and ESG disclosures and/or other corporate governance mechanisms.

\subsection{Limitations and future research avenues}

There is considerable scope for developing new research. This paper illustrates the importance of considering accounting conservatism in food and beverage sectors broadly, looking beyond the level of earnings quality. In this respect, the conceptual framework of IASB is a useful tool that can be applied to future research of food and drink industries focusing on specific accounts such as IAS 2 and/or IAS 18, which are extremely important for this industry. Another stream of research proposes a comparative analysis with other industries: while the relative importance of such impact may differ by industry, it is undoubtedly critical to evaluate each to capture the full magnitude of conservatism and to identify the levers for managing earnings quality. 


\section{References}

Abdel-Kader, M. and Luther, R. (2006), "Management accounting practices in the British food and drinks industry", British Food Journal, Vol. 108 No. 5, pp. 336-357.

Acharya, V.V. and Lambrecht, B.M. (2015), "A theory of income smoothing when insiders know more than outsiders, Review of Financial Studies, pp. 2534-2574.

Albrecht, W.D. and Richardson, F. M. (1990), "Income smoothing by economy sector", Journal of Business Finance \& Accounting, Vol. 17 No. 5, pp. 713-730.

Almeida, J.E.F.D., Sarlo Neto, A., Bastianello, R.F. and Moneque, E.Z. (2012), "Effects of income smoothing practices on the conservatism of public companies listed on the BM \& FBOVESPA", Revista Contabilidade \& Finanças, Vol. 23 No. 58, pp. 65-75.

Amir, E. (1996), "The effect of accounting aggregation on the value-relevance of financial disclosures: The case of SFAS No. 106", The Accounting Review, pp. 573-590.

Amran, N.A. and Abdul Manaf, K.B. (2014), "Board independence and accounting conservatism in Malaysian companies", Procedia-Social and Behavioral Sciences, Vol. 164, 403-408.

André, P., Filip, A. and Paugam, L. (2015), "The effect of mandatory IFRS adoption on conditional conservatism in Europe", Journal of Business Finance \& Accounting, Vol. 42 No. 3-4, pp. 482-514.

Baik, B., Choi, S. and Farber, D.B. (2020), "Managerial ability and income smoothing", The Accounting Review, Vol. 95 No. 4, pp. 1-22.

Balachandran, S. and Mohanram, P. (2011), "Is the decline in the value relevance of accounting driven by increased conservatism?", Review of Accounting studies, Vol. 16 No. 2, pp. 272301.

Ball, R. and Brown, P. (1968), “An empirical evaluation of accounting income numbers”, Journal of accounting research, pp. 159-178.

Ball, R., Kothari S.P. and Robin, A. (2000), “The Effect of International Institutional Factors on 
Properties of Accounting Earnings", Journal of Accounting and Economics, Vol. 29 No. 1, pp. $1-51$.

Ball, R. and Shivakumar, L. (2005), "Earnings Quality in U.K. Private Firms: Comparative Loss

Recognition Timeliness", Journal of Accounting and Economics, Vol. 39, pp. 83- 128.

Bandyopadhyay, S.P., Chen, C., Huang, A.G. and Jha, R. (2009), "Accounting conservatism and the temporal trends in current earnings' ability to predict future cash flows versus future earnings: Evidence on the trade-off between relevance and reliability", Contemporary Accounting Research, Forthcoming.

Barnea, A., Ronen, J. and Sadan, S. (1976), "Classificatory smoothing of income with extraordinary items", The Accounting Review, Vol. 51 No. 1, pp. 110-122.

Basu, S. (1997), "The conservatism principle and the asymmetric timeliness of earnings", Journal of Accounting and Economics, Vol. 24, pp. 3-37.

Beaver, W. and Ryan, S. (2005), "Conditional and Unconditional Conservatism: Concepts and Modeling”, Review of Accounting Studies, Vol. 10, pp. 269- 309.

Beidleman, C.R. (1973), "Income smoothing: The role of management", The Accounting Review, Vol. 48 No. 4, pp. 653-667.

Belkaoui, A. and Picur, R.D. (1984), "The Smoothing of Income Numbers: Some Empirical Evidence on Systematic Differences Between Core and Periphery Industrial Sectors", Journal of Business Finance \& Accounting, pp. 527-45.

Bowen, R.M. (1981), "Valuation of earnings components in the electric industry", The Accounting Review, Vol. 56, pp. 1-22.

Chen, Q., Hemmer, T. and Zhang, Y. (2007), "On the Relation Between Conservatism in Accounting Standards and Incentives for Earnings Management", Journal of Accounting Research, Vol. 45, No. 3, pp. 541-565.

Collins, D.W., Maydew, E.L. and Weiss, I.S. (1997), "Changes in the value-relevance of earnings and book values over the past forty years", Journal of Accounting and Economics, Vol. 24 No. 1, pp. 39-67.

Dechow, P.M. and Skinner, D.J. (2000), "Earnings management: Reconciling the views of accounting academics, practitioners, and regulators", Accounting horizons, Vol. 14 No. 2, pp. 235-250.

Delkhosh, M. and Sadeghi, M. (2017), "The effect of accounting conservatism and earnings management on earnings quality, International Journal of Accounting and Economics Studies, Vol. 5 No. 2, pp. 157-162.

Dickhaut, J., Basu, S., McCabe, K. and Waymire, G. (2010), "Neuroaccounting: Consilience between the Biologically Evolved Brain and Culturally Evolved Accounting Principles", Accounting Horizons, Vol. 24 No. 2, pp. 221-5.

Easton, P.D. and Harris, T.S. (1991), "Earnings as an explanatory variable for returns", Journal of Accounting Research, Vol. 29 No. 1, pp. 19-36.

Easton, P.D. and Pae, J. (2004), "Accounting conservatism and the relation between returns and accounting data", Review of Accounting Studies, Vol. 9 No. 4, pp. 495-521.

Eckel, N. (1981), "The income smoothing hypothesis revisited", Abacus, Vol. 17 No. 1, pp. 28-40.

Eddie, I. and Yamaguchi, T. (2018), “Accounting conservatism and Income Smoothing after the Japanese Sarbanes-Oxley Act", Available at SSRN 3168280.

Enache, L. and García-Meca, E. (2019), "Board composition and accounting conservatism: the role of business experts, support specialist and community influential", Australian Accounting Review, Vol 29 No. 1, pp. 252-265.

Entwistle, G.M. and Phillips, F. (2003), "Relevance, reliability, and the earnings quality debate", Issues in accounting education, Vol. 18 No. 1, pp. 79-92.

EU Commission (2020). Food and drink industry. Accessed 08 October 2020 at link 
https://ec.europa.eu/growth/sectors/food_en\#: :text=The $\% 20$ food $\% 20 \mathrm{and} \% 20 \mathrm{drink} \% 20 \mathrm{ind}$ ustry,specialities\%20are\%20well\%20appreciated\%20overseas.

Fairfield, P.M., Sweeney, R.J. and Yohn, T.L. (1996), "Accounting classification and the predictive content of earnings", The Accounting Review, pp. 337-355.

FDEA (Food and Drink Exporters Association, 2019). Retrived from https://www.fdf.org.uk/corporate_pubs/FDF-Industry-Report-2020.pdf

FoodDrinkEurope. (2016). A competitive EU food and drink industry for growth and jobs: Ambitions for 2025 - Priorities and policy recommendations. Retrieved from www.fooddrinkeurope.eu. Accessed on October 12, 2020

FoodDrinkEurope. (2019). Data \& Trends. EU Food \& Drink Industry 2019. Retrieved from www.fooddrinkeurope.eu. Accessed on October 12, 2020.

FoodDrinkEurope. (2020). FoodDrinkEurope \& EFFAT Joint Statement: Covid-19. Retrieved from www.fooddrinkeurope.eu. Accessed on October 12, 2020

Francis, J. and Schipper, K. (1999), "Have financial statements lost their relevance?", Journal of Accounting Research, Vol. 37 No. 2, pp. 319-352.

Fudenberg, D. and Tirole, J. (1995), "A theory of income and dividend smoothing based on incumbency rents", Journal of Political Economy, Vol. 103 No. 1, pp. 75-93.

Gassen, J., Fülbier, R.U. and Sellhorn, T. (2006), “International differences in conditional conservatism: the role of unconditional conservatism and income smoothing", European Accounting Review, Vol. 15 No. 4, pp. 527-564.

Givoly, D. and Hayn, C. (2000), "The changing time-series properties of earnings, cash flows and accruals: Has financial reporting become more conservative?", Journal of Accounting and Economics, Vol. 29 No. 3, pp. 287-320.

Jacob, A. (2019), "Accounting conservatism and the risk of bankruptcy in the Nigerian food and beverage firms", Leibniz Information Centre for Economics, Provided in Cooperation with: International Accounting and Taxation Research.

Jenkins, D.S., Kane, G.D. and Velury, U. (2009), "Earnings conservatism and value relevance across the business cycle", Journal of Business Finance \& Accounting, Vol. 36 No. 9-10, pp. 10411058 .

Kanagaretnam, K., Lim, C.Y. and Lobo, G.J. (2014), "Influence of national culture on accounting conservatism and risk-taking in the banking industry", The Accounting Review, Vol. 89 No. 3, pp. 1115-1149.

Kieso, D., Weygandt, J. and Warfield, T. (2004), Intermediate accounting, New York, NY: Wiley.

Kim, B.H. and Pevzner, M. (2010), "Conditional accounting conservatism and future negative surprises: An empirical investigation”, Journal of Accounting and Public Policy, Vol. 29 No. 4, pp. 311-329.

Kwon, S.S., Yin, Q.J. and Han, J. (2006), "The effect of differential accounting conservatism on the "over-valuation" of high-tech firms relative to low-tech firms", Review of Quantitative Finance and Accounting, Vol. 27 No. 2.

Lara, J.M.G., Osma, B.G. and Penalva, F. (2016), “Accounting conservatism and firm investment efficiency”, Journal of Accounting and Economics, Vol. 61 No. 1, pp. 221-238.

Lara, J.M.G., Osma, B.G. and Penalva, F. (2020), "Conditional conservatism and the limits to earnings management", Journal of Accounting and Public Policy, Vol. 39 No. 4.

Leuz, C., Nanda, D. and Wysocki, P.D. (2003), "Earnings management and investor protection: an international comparison", Journal of Financial Economics, Vol. 69 No. 3, pp. 505-527.

Lev, B. and Zarowin, P. (1999), "The boundaries of financial reporting and how to extend them", Journal of Accounting research, Vol. 37 No. 2, pp. 353-385.

Leventis, S., Dimitropoulos, P. and Owusu-Ansah, S. (2013), "Corporate governance and accounting 
conservatism: Evidence from the banking industry", Corporate Governance: An International Review, Vol. 21 No. 3, pp. 264-286.

Lim, C.Y., Lee, E., Kausar, A. and Walker, M. (2014), "Bank accounting conservatism and bank loan pricing", Journal of Accounting and Public Policy, Vol. 33 No. 3, pp. 260-278.

Mann, R., Adebanjo, O. and Kehoe, D. (1999b), "Best practices in the UK food and drinks industry", British Food Journal, Vol. 101 No. 3, pp. 184-99.

Michelson, S.E., Jordan-Wagner, J. and Wootton, C.W. (1995), “A Market Based Analysis of Income Smoothing”, Journal of Business Finance \&Accounting, pp. 1179-93.

Michelson, S.E., Jordan-Wagner, J. and Wootton, C.W. (2000), "The Relationship Between the Smoothing of Reported Income and Risk-Adjusted Returns", Journal of Economics and Finance, pp. 141-59.

Nasev, J. (2009), Conditional and unconditional conservatism: Implications for accounting based valuation and risky projects, Springer Science \& Business Media.

Ohlson, J.A. (1995), "Earnings, book values, and dividends in equity valuation”, Contemporary accounting research, Vol. 11 No. 2, pp. 661-687.

Oyedokun, G.B. and Salisu, S. (2018), "Corporate Governance and Accounting Conservatism in Nigerian Foods and Beverages Firms", American Journal of Economics, Finance and Management, Vol. 4 No. 4, pp. 124-133.

Penman, S.H. and Zhang, X.J. (2002), "Accounting conservatism, the quality of earnings, and stock returns", The Accounting Review, Vol. 77 No. 2, pp. 237-264.

Pope, P.F. and M. Walker (1999), "International Differences in the Timeliness, Conservatism, and Classification of Earnings", Journal of Accounting Research, Vol. 37, pp. 53-87.

Revsine, L., Collins, D.W., Johnson, W.B., Mittelstaedt, H.F. and Soffer, L.C. (1999), Financial reporting \& analysis, Upper Saddle River, New Jersey New Jersey: Prentice Hall.

Richardson, G. and Tinaikar, S. (2004), "Accounting based valuation models: what have we learned?", Accounting \& Finance, Vol. 44 No. 2, pp. 223-255.

Ryan, S.G. (2006), "Identifying conditional conservatism”, European Accounting Review, Vol. 15 No. 4, pp. 511-525.

Santi, M., Ghani K. and Puspitasari, E. (2017), "Analysis of unconditional conservatism and earnings quality of financial reporting practices in Indonesia upon IFRS convergence", Management \& Accounting Review, Vol. 16 No. 1, pp. 75-88.

Stanga, K.G. (1980), "The relationship between relevance and reliability: Some empirical results", Accounting and Business Research, Vol. 11 No. 41, pp. 29-39.

Statista (2020). https://www.statista.com/outlook/253/100/food-beverages/worldwide\#market-users. Accessed October 12, 2020.

Suleiman, S. and Anifowose, M. (2014), "Corporate Governance and Conditional Accounting Conservatism in Nigeria Listed Food and Beverages Firms", International Journal of Accounting and Taxation, Vol. 2 No. 2, pp. 65-84.

Watts, R.L. (2003), "Conservatism in accounting part I: Explanations and implications", Accounting horizons, Vol. 17 No. 3, pp. 207-221.

Zhang, J. (2020), "Essays on loss reserving and accounting conservatism”, Ph.D. Dissertation submitted to the Temple University Graduate Board.

Zhang, J. (2000), "Conservative accounting and equity valuation”, Journal of Accounting and Economics, Vol. 29 No. 1, pp. 125-149.

Zhong, Y. and Li, W. (2017), “Accounting conservatism: A literature review”, Australian Accounting Review, Vol. 27 No. 2, pp. 195-213. 


(

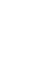

(1)

(1)

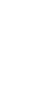

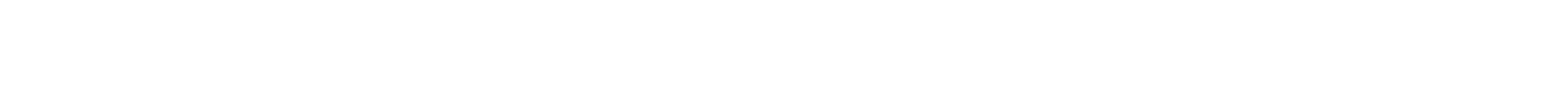

(2)

.

.

8

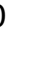


Dear Editors,

We are pleased to submit a new version of the manuscript (ID BFJ-11-2020-1041) titled "Accounting conservatism and Income Smoothing practices in EU food and drink industry".

We are very grateful for your contribution to improving our study. We do hope our revised manuscript will be considered for publication in British Food Journal.

Notice that we have decided to include a third author that helped us a lot during all the reviewing steps

*Answers are in bold format

DEADLINE: 19-Mar-2021

Editor's comments:

Dear authors,

I am happy to say that your manuscript has been appreciated by me and the reviewers. However, some changes are needed. Please, follow the suggestion of the reviewers as well as the following:

- Motivation of the Paper. in the introduction I do not understand and see clearly the theoretical contribution of the paper. I think the paper, at the present form, partially fails to formulate a research problem, which is of interest. We have partial answers on what we know now about the topic and what we do not know. The author should more in detail and in a more systematic way present answer on these questions, but also what we need to know. Why is this important, for research, for practise?

Thanks for your comment. We have re-shaped the introduction to better clear the theoretical contribution of the paper. We have also emphasized the research problem and match all issues in a more systematic way.

- literature. The paper should be grounded more on: a) food literature, this helps you in better develop a contribution for this stream of research; b) business management RECENT literature

We have added many contributions (some of them suggested by the reviewers) on business management, accounting and food literature as well. Now the Literature Review should be more recent and clear.

- Building your discussion: I would suggest that a discussion section be more comprehensively developed that links back to your initial research questions and a clear statement of proposed contributions, once you have reframed your arguments and developed some propositions. What should we, as readers, take away regarding your study? What are the key theoretical contributions that are gained? How can these findings contribute to the literature stream associated with good businesses? What do we know about this literature stream now that we have read your study? What future research should be conducted within this literature stream that can be extended based upon your study?

Discussion of the paper was strongly improved, specifically in the part of Implications and Contributions. We have also decided to divided the Conclusions in three different sub-sections: Discussion, Implication and Limitations/FutureStudies. Now it's clear

This is what I often call "closing the loop". Specifically, you a) state in the introduction that there is a gap (your research questions), and you plan to address the gap theoretically; b) present a formally developed and very focused literature review that gives the rational for the study and develop propositions that reflect this gap; and c) "Close the loop", by developing your discussion section that ties back to the research question(s). In the end, you hope that the reader has been able to read the article and see the article, in its entirety, as encapsulating the resolution of a theoretical or empirical gap. 


\section{Thanks for it. We have state the research question, developed a very focused literature review and improve the discussion in line with our research questions.}

Good luck with the revised version

Reviewer(s)' and comments to Author:

Reviewer: 1

Recommendation: Major Revision

Comments:

I would like to report some relevant literature that you might address in your review. These are mainly recent papers from the finance and accounting field, and I list them below. I would also recommend the following:

- Please, remember to attach an abstract, for I was not able to view it;

\section{We have added the abstract according to the BFJ guidelines.}

- I would improve on the positioning of this paper within the food and drink industry, mainly by unfolding the issue of why your conclusions would be particularly suitable thereto: why specifically food and drink? Why accounting conservatism is relevant in the context of this industry? I suggest giving a crossindustry view on accounting conservatism, then highlighting the specifities of the food and drink industry.

We stressed the motivation of choosing the food and drink industry. In the introduction and discussion specifically.

- Correlation matrices in the appendix might be deleted, and replaced with just one sentence on the major insights therefrom: e.g., you might write "Correlation matrices (not reported) have too been computed with respect to sub-industries [...].”.

We did it. We have eliminated the matrices in the appendix and we have added a sentence in the descriptive statistics.

\section{SUGGESTED LITERATURE:}

- Acharya, V. V.; Lambrecht, B. M. (2015). A theory of income smoothing when insiders know more than outsiders. Review of Financial Studies, 2534- 2574.

- Bao, B. H.; Bao, D. H. (2004). Income smoothing, earnings quality and firm valuation. Journal of Business Finance \& Accounting, 31(9-10), 1525-1557.

- Chen, Q.; Hemmer, T.; Zhang, Y. (2007). On the relation between conservatism in accounting standards and incentives for earnings management. Journal of Accounting Research, 45(3), 541-565.

- Eddie, I.; Yamaguchi, T. (2018). Accounting Conservatism and Income Smoothing after the Japanese Sarbanes-Oxley Act. Available at SSRN 3186280.

- Delkhosh, M.; Sadeghi, M. (2017). The effect of accounting conservatism and earnings management on earnings quality. International Journal of Accounting and Economics Studies, 5(2), 157-162.

- Sugiarto, H. V. S.; Fachrurrozie, F. (2018). The determinant of accounting conservatism on manufacturing companies in Indonesia. Accounting Analysis Journal, 7(1), 1-9.

- Zhong, Y.; Li, W. (2017). Accounting conservatism: A literature review. Australian Accounting Review, 27(2), 195-213.

- Lara, J. M. G.; Osma, B. G.; Penalva, F. (2016). Accounting conservatism and firm investment efficiency. Journal of Accounting and Economics, 61(1), 221-238. 
- Lara, J. M. G.; Osma, B. G.; Penalva, F. (2020). Conditional conservatism and the limits to earnings management. Journal of Accounting and Public Policy, 39(4).

Thanks for the literature suggested. We have added all above contributions. Now the LR is more recent and updated. Consequently, we have decided to divide the LR in three sub-sections: Accounting Conservatism, Income Smoothing and Relationships between AC-IS.

Additional Questions:

1. Originality: Does the paper contain new and significant information adequate to justify publication?: Yes, particularly because it addresses an industry - that is, food and drink - with which the literature has hitherto dealt not so frequently with regard to accounting conservatism issues, in spite of its relevance on the European manufacturing sector. In fact, the author(s) claim(s) to be the first.

\section{Thanks for this!}

2. Relationship to Literature: Does the paper demonstrate an adequate understanding of the relevant literature in the field and cite an appropriate range of literature sources? Is any significant work ignored?: I am more familiar with accounting conservatism and income smoothing in the financial sector, yet many relevant papers I have read in order to get a general knowledge on the topic have been correctly included. However, some relevant literature might be missing: I report it in my comments directly addressed to the authors. I would just suggest devoting greater attention to reviewing the literature on corporate strategy and managerial practices in the food and drink industry, as it is mainly cited in order to (correctly) highlight its economic relevance.

Thanks for this. As you suggested, we added relevant papers to get a general knowledge of the topic.

3. Methodology: Is the paper's argument built on an appropriate base of theory, concepts, or other ideas? Has the research or equivalent intellectual work on which the paper is based been well designed? Are the methods employed appropriate?: Yes: the models applied are drawn from a very significant and mature stream of knowledge, widely tested in accounting-based research. Therefore, I find the "base of theory, concepts, or other ideas" wholly consistent and perfectly valid. Although I would recommend expanding the empirical part of the analysis, I am perfectly fine with the research design which has been followed, especially because of its use of a "rule of thumb"based on purely accounting data to furtherly refine an econometric setting centred around market-based inputs as well. This might be too narrow and focused (again, it would need some more expansion), yet makes a lot of practical sense and strengthens the reliability of results.

\section{Thanks, we have stressed this part on methodology.}

4. Results: Are results presented clearly and analysed appropriately? Do the conclusions adequately tie together the other elements of the paper?: Yes: conclusions are well in line with the analysis which has been conducted, particularly because the author(s) test(s) a specific hypothesis on the relationship between (past) income smoothing and accounting conervatism, which per se "ties together" the whole of this work. I would just recommend performing certain robustness tests (e.g., by amending the sample to remove countries with too few observations) in order to increase the empirical evidence of results.

\section{We set different robustness tests to increase empirical evidence of our results}

5. Implications for research, practice and/or society: Does the paper identify clearly any implications for research, practice and/or society? Does the paper bridge the gap between theory and practice? How 
can the research be used in practice (economic and commercial impact), in teaching, to influence public policy, in research (contributing to the body of knowledge)? What is the impact upon society (influencing public attitudes, affecting quality of life)? Are these implications consistent with the findings and conclusions of the paper?: Conclusions do rifghtfully highlight the importance of topics which are specific to the food and drink industry, i.e. the relationship between accounting practices and the achievement of ESG targets: I would recommend devoting greater attention to this. Also, the potential connections of this research to similar ones on other industries, maybe from a comparative standpoint, are correctly indicated. In general, I think that the practical and policy implications might be furtherly developed. The author (s) seem(s) to suggest that regulatory bodies should, at the same time, limit the possibility for companies to be discretionary in their reporting (even because the EPS of income-smoothing firms do not benefit from accounting conservatism) but, also, not provide any disincentive to perform conditional accounting conservatism, as stock returns do benefit from it.

\section{Thanks! We dedicated one sub-section to Implications focusing on your suggestions}

6. Quality of Communication: Does the paper clearly express its case, measured against the technical language of the field and the expected knowledge of the journal's readership? Has attention been paid to the clarity of expression and readability, such as sentence structure, jargon use, acronyms, etc.: Although the message is very clear, some phrases and sentences might be misleading and need revision. In general, the quality of writing should be improved: for this purpose, I would recommend using a professional proof reading service. I found the accounting and finance-based concepts easy to understand (I would just ask to better explain the theoretical relationship between soaring stock returns and decreasing investors' optimism with regard to income smoothing). Nevertheless, I think that readers with a specific knowledge on the food and drink industry would find this paper highly intriguing because of its value-adding focus on that area, filling a significant literature gap.

\section{We used a proof reading service of Americal Journal Editing}

\section{Reviewer 2}

\section{Recommendation: Major Revision}

Comments:

I recommend a deepening major revision considering all the comments above, knowing that this version of the article has a number of shortcomings in relation to findings, lack of sophistication in methodology and clarification of data.

\section{Additional Questions:}

1. Originality: Does the paper contain new and significant information adequate to justify publication?: Thank you for the opportunity to read your manuscript. The paper focuses on accounting conservatism and income smoothing practices in the F\&B Industry. For this reason, I believe that it is potentially suitable for this journal.

The match between acc. conservatism and income smoothing practices is interesting, although the level of detail provided is insufficient and critical analysis is lacking. It needs refinements on literature gaps, theoretical and practical contributions, and specifications regarding the research method. The conclusions could be better supported strengthen the contextualization of these topics in literature and the methodology adopted for the investigation. Overall, the paper can proceed with the review process, conditionally. For these reasons I do not believe this paper in the current form is suitable for an immediate publication in British Food Journal. Therefore, hereafter some personal suggestions that the authors might consider to improve your work. I wish the authors the very best in further iterations of this paper. 
2. Relationship to Literature: Does the paper demonstrate an adequate understanding of the relevant literature in the field and cite an appropriate range of literature sources? Is any significant work ignored?: The literature review is present in the introduction as well as in the third paragraph but it should be improved and updated. About Conservatism in accounting, I suggest:

Zhong, Y., \& Li, W. (2017). Accounting conservatism: A literature review. Australian Accounting Review, 27(2), 195-213.

Biddle, G. C., Ma, M. L., \& Song, F. M. (2020). Accounting conservatism and bankruptcy risk. Journal of Accounting, Auditing and Finance, Forthcoming.

Dai, L., \& Ngo, P. (2020). Political uncertainty and accounting conservatism. European Accounting Review, $1-32$.

Basu, S., \& Waymire, G. B. (2017). Historical cost and conservatism are joint adaptations that help identify opportunity cost. Accounting, Economics, and Law: A Convivium, 9(1).

With a special focus on the food sector (the journal level is low, but the contents could be useful),

Oyedokun, G. B., \& Salisu, S. (2018). Corporate Governance and Accounting Conservatism in Nigerian Foods and Beverages Firms. American Journal of Economics, Finance and Management, 4(4), 124-133.

Obviously, these updates are important in order to contribute to the current discussion on these topics.

At the same time, about the income smoothing practices I suggest:

Baik, B., Choi, S., \& Farber, D. B. (2020). Managerial ability and income smoothing. The Accounting Review, 95(4), 1-22.

Chen, Y. S., Chiu, S. C., Lin, S., \& Wu, K. H. (2019). Corporate social responsibility and income smoothing: Supply chain perspectives. Journal of Business Research, 97, 76-93. (This may be useful to support your discussion \& conclusions in paragraph 6).

Thanks for this. We have added all above papers as you may see from the revised paper and we have also re-structured the LR section.

The problem is that your references cover only the period $1973-2010$. The sole current elements considered are technical docs e.g. "Statista" and FoodDRinkEurope, but in my opinion, it is not enough. At the moment, paragraphs 2, 3 and 4 have the same level, but it is not justifiable. In this sense, I suggest to adopt a different structure. You could better introduce the selection of F\&B sector in the introduction and then merge paragraph 2 with paragraph 4 . In other words the current paragraph 2 is useful to justify your submission in this journal but in my opinion it is not adequate to justify the target of your selection and the comparison between 2016 and 2019. Furthermore, this time-lapse is not useful for your investigation. In other words, the authors could strengthen the link between this sector and its relevance on these topics. Paragraph 3 is dividend in two sections (3.1 and 3.3?) but they are described as two different parts and only few sentences at the end on 3.3 try to find a match between them. I invite to better describe the relationship between them also, if you can, with a figure that you can use as a "conceptual model". This point would help you to give a structure to your conclusions and emphasize the value added. In the end, the literature review constitutes your premise and argumentation to identify literature gaps. The current format is not appropriate.

Note: after paragraph 3.1 you wrote 3.3 and not 3.2.

Thanks for the above points. This is what we did for LR:

- Added the above contributions overcoming the problem of reference period 1973-2010

- Found different and other sources for Food analysis together with Statista, FoodDrinkEurope

- Re-Structured the LR in three different sections 2.1. Accounting Conservatism, 2.2. Income Smoothing, 2.3. Relationship AC-IS in order to get the final hypothesis developed. 
- Merged the paragraph 2 (EU Economic bulletin of food and drink) with paragraph of our research analysis

3. Methodology: Is the paper's argument built on an appropriate base of theory, concepts, or other ideas? Has the research or equivalent intellectual work on which the paper is based been well designed? Are the methods employed appropriate?: This study can be improved with a more focused and structured outline of the research setting of analysis. In more detail, the authors can consider the following:

- I personally suggest merging and reshaping paragraph 2 into paragraph 4.

\section{We have better structured the research method}

- 4.1: this paragraph is poor, you applied tables without a description and an explanation in the body text of the paper. You could better describe this methodological process and you could justify your choices. Furthermore, your sample consists of international companies but you do not specify (as I could assume) if all these players are IFRS adopter or if you considered the consolidated position or the separate one, or other info useful to better understand the composition. In this way also their dimension could be interesting.

\section{We have better described the sampling process of analysis. We also specified that all players are IFRS adopters so that we use data from consolidated financial statements}

- 4.2: In this paragraph, the variables could be better supported and analyses. Furthermore, you do not fix the year of the analysis. This is an important element for a quantitative investigation.

\section{Thanks for it. We have fixed it.}

4. Results: Are results presented clearly and analysed appropriately? Do the conclusions adequately tie together the other elements of the paper?: The description of findings is below my expectations. You titled paragraph 5 with "regression results", but 5.1 is "descriptive statistics" and 5.2 "findings". I think it should be reshape and in order to confirm the results of your OLS model you should disclose and discuss the main tests to verify the quality of you regressions (or the reason why you did not performed them). Then you have also to explain why you think that a sole year is enough to perform this analysis.

\section{Thanks for it we have justified it}

5. Implications for research, practice and/or society: Does the paper identify clearly any implications for research, practice and/or society? Does the paper bridge the gap between theory and practice? How can the research be used in practice (economic and commercial impact), in teaching, to influence public policy, in research (contributing to the body of knowledge)? What is the impact upon society (influencing public attitudes, affecting quality of life)? Are these implications consistent with the findings and conclusions of the paper?: In the conclusion section, you should strengthen the match between your findings and the literature.

\section{Thanks for it. As you can see, we have expanded the section of implications improving contents}

6. Quality of Communication: Does the paper clearly express its case, measured against the technical language of the field and the expected knowledge of the journal's readership? Has attention been paid to the clarity of expression and readability, such as sentence structure, jargon use, acronyms, etc.: Writing style: In general, the writing style is appropriate for the journal.

As you notice, we agreed with all the comments. We would like to take this opportunity to express our sincere thanks to the reviewers who identified areas of our manuscript that needed corrections or modification in order to improve the quality of our study. The manuscript has certainly benefited from these insightful revision suggestions.

We hope that the revised manuscript is accepted for publication in British Food Journal. 
Sincerely Yours,

The Authors 